Graduate Institute of

International and Development Studies Working Paper

No: 04/2011

\title{
Where It All Began: \\ Lending of Last Resort and the Bank of England during the Overend, Gurney Panic of 1866
}

\author{
Marc Flandreau \\ Graduate Institute of International Studies \\ Stefano Ugolini \\ Scuola Normale Superiore, Pisa
}

\begin{abstract}
The National Monetary Commission was deeply concerned with importing best practice. One important focus was the connection between the money market and international trade. It was said that Britain's lead in the market for "acceptances" originating in international trade was the basis of its sterling predominance. In this article, we use a so-far unexplored source to document the portfolio of bills that was brought up to the Bank of England for discount and study the behavior of the Bank of England during the crisis of 1866 (the so-called Overend- Gurney panic) when the Bank began adopting lending of last resort policies (Bignon, Flandreau and Ugolini 2011). We compare 1865 (a "normal" year) to 1866. Important findings include: (a) the statistical predominance of foreign bills in the material brought to the Bank of England; (b) the correlation between the geography of bills and British trade patterns; (c) a marked contrast between normal times lending and crisis lending in that main financial intermediaries and the "shadow banking system" only showed up at the Bank's window during crises; (d) the importance of money market investors (bills brokers) as chief conduit of liquidity provision in crisis; (e) the importance of Bank of England's supervisory policies in ensuring lending-of-lastresort operations without enhancing moral hazard. An implication of our findings is that Bank of England's ability to control moral hazard for financial intermediaries involved in acceptances was another reason for the rise of sterling as an international currency.
\end{abstract}

(C) The Authors.

All rights reserved. No part of this paper may be reproduced without the permission of the authors. 


\title{
Where It All Began: \\ Lending of Last Resort and the Bank of England \\ during the Overend, Gurney Panic of 1866
}

\author{
February, 16, 2011 \\ Marc Flandreau (Graduate Institute of International Studies and Developement, Geneva, Switzerland) \\ and Stefano Ugolini (Scuola Normale Superiore, Pisa, Italy)^
}

\begin{abstract}
:
The National Monetary Commission was deeply concerned with importing best practice. One important focus was the connection between the money market and international trade. It was said that Britain's lead in the market for "acceptances" originating in international trade was the basis of its sterling predominance. In this article, we use a so-far unexplored source to document the portfolio of bills that was brought up to the Bank of England for discount and study the behavior of the Bank of England during the crisis of 1866 (the so-called OverendGurney panic) when the Bank began adopting lending of last resort policies (Bignon, Flandreau and Ugolini 2011). We compare 1865 (a "normal" year) to 1866. Important findings include: (a) the statistical predominance of foreign bills in the material brought to the Bank of England; (b) the correlation between the geography of bills and British trade patterns; (c) a marked contrast between normal times lending and crisis lending in that main financial intermediaries and the "shadow banking system" only showed up at the Bank's window during crises; (d) the importance of money market investors (bills brokers) as chief conduit of liquidity provision in crisis; (e) the importance of Bank of England's supervisory policies in ensuring lending-of-lastresort operations without enhancing moral hazard. An implication of our findings is that Bank of England's ability to control moral hazard for financial intermediaries involved in acceptances was another reason for the rise of sterling as an international currency.
\end{abstract}

\footnotetext{
^. Paper prepared for the Conference "A Return to Jekyll Island: the Origins, History, and Future of the Federal Reserve", Jekyll Island, November 5-6 2010. Many thanks to Will Roberds and Mike Bordo for their comments on an early draft. We also thank our discussant Barry Eichengreen for detailed comments and Charlie Calomiris for valuable feedback.

We are immensely grateful to the archivists of the Bank of England (Jeanette Sherry, Lara Webb, and Ben White) for their help and patience with our requirements. Extremely dedicated research assistance from Pierre Turgeon is also gratefully acknowledged. We thank the conference organizers David Altig, James Nason, Will Roberds, and Michael Bordo for their invitation to contribute.
} 
During the consultations organized after 1908 by the US National Monetary Commission with a view to create the Federal Reserve System, banker Paul Warburg delivered an account of the functioning of the money market in "Europe" (Warburg 1910). He drew a comparison with the American system. In America, he explained, the money market was based on the stock exchange. As there was no central bank standing ready to rediscount short-term commercial credit instruments ("acceptances"), the liquid portion of the money market was made up of repos to the stock exchange. Those with available short-term cash lent it to stock market dealers in exchange for securities, and got their cash back or renewed their positions periodically.

According to Warburg, this arrangement lacked resilience. It made the US financial system vulnerable to balance-of-payment shocks. If payments abroad increased, e.g. in the event the trade balance deteriorated and foreign creditors demanded settlement, cash was withdrawn. And since cash was with the stock exchange, it was withdrawn from there and took speculators wrong-footed. This forced fire sales. Ensuing decline in the price of securities (i.e. the deterioration of collaterals) prompted brokers to increase their margin requirements. Lenders distributed money sparingly. The balance-of-payment shock morphed into a stock exchange crisis, then into a credit crisis. Reluctance to lend and declines in values completed the circle and led to commercial bankruptcies.

By contrast, in Europe - Warburg reasoned - the existence of a large volume of bills that could be rediscounted at the central bank provided more leeway and facilitated financial stabilization. Most contemporary observers (and this included US economists and policy makers involved in the debates surrounding the US National Monetary Commission) were struck by the fact that the tradable bill or "acceptance" was the staple instrument in European money markets. Their generous availability, their liquidity, and the fact that central banks stood willing to rediscount them in crises were seen as a source of financial resilience. When liquidity requirements grew, banks could turn to the central bank and rediscount acceptances. The liquidity thus obtained enabled banks to keep supporting their customers. The central bank thus acted as a lender of last resort. The result was that Europeans could deal with crises more effectively than Americans. The mix of acceptances and central bank support was seen as Europe's secret recipe for financial stability, and the only thing the US needed to do was removing the regulatory constraints that impeded the emergence of such a market. This would bring one century of financial stability. History may have eventually decided otherwise, but later scholars have generally concurred that there was widespread belief that creating a market for acceptances " $a$ Europe" would provide the public good of financial stability.

"Europe" was code for England. While the National Monetary Commission concerned itself with studying other central banks, US bankers and policy makers had cast their sights on the Bank of England and the London market for acceptances, the center of world liquidity. This is natural, since this is where best practice was defined. Franc and mark bills enjoyed some international circulation, 
but they were junior to sterling. ${ }^{1}$ Moreover, beyond the goal of finding a remedy to crises, one concern of the National Monetary Commission was to devise ways to short-circuit London and save on the "tribute" that was paid annually to UK bankers in the form of acceptance commissions. Warburg and his supporters intended to defeat Europe on its own turf, and this started in London (Broz 1997).

At that time, the central banking wisdom that prevailed in central banking was what Frank Fetter would call the "British monetary orthodoxy" (Fetter 1965). A prominent feature of this orthodoxy was its identification (which contemporaries associated with the Bank Charter Act of 1844) of the central bank's key lending rate (the discount rate) as the legitimate policy tool to protect the gold reserve and peg the external value of the currency, although some observers grew uneasy with the interest rate volatility this induced and made suggestions for improvements (Palgrave 1903). ${ }^{2}$ But this said little as to how one should construct a market.

The National Monetary Commission produced four reports on the English banking system. ${ }^{3}$ There were two books. One was an already published book due to an Austrian scholar, Eugen Von Phillippovich, now translated from German (Phillippovich 1910). It was devoted to the historical evolution of the relations between the Bank of England and the State. The other was a joint volume, with contributions of varied lengths by a number of City experts (Withers et al. 1910). And there were two pamphlets. The first was due to Jacobs (1910), and the other was the already mentioned contribution by Warburg (1910). The reports by Jacobs and Warburg were superlative on the beauties of the European system, but they were concise. The contribution by the City writers also lacked detail. Withers dealt with "the merchant bankers and accepting houses" in less than five pages, although there was laid manifestly the secret of making fire. ${ }^{4}$ A characteristic of most reports submitted to the National Monetary Commission is that they generally abstracted from more tedious microstructure aspects. ${ }^{5}$ This omission is intriguing. It may have reflected an English antipathy for detail. But a lot of relevant information was concealed that way. We fail to understand why American counterparts were content with material that was so general it could hardly serve as the basis of a blueprint for monetary design. This conflicts with the National Monetary Commission's mission to inspire the creation of a market and new instruments - a mission that would succeed or fail on microeconomic cleverness, not on abstract principles.

\footnotetext{
${ }^{1}$ See Lindert (1967); Flandreau and Gallice (2005); Flandreau and Jobst (2006).

2 R. H. Inglis Palgrave was an editor of The Economist between 1877 and 1883, reflecting the continued influence of this journal in setting the tune of proper policy making.

${ }^{3}$ We leave aside the statistical volumes that combined information on various countries, such as e.g. Aldrich (1910).

${ }^{4}$ Withers (1910, p. 56) has an intriguing digression on the Bank of England being the "final arbiter" of the market when the credit of certain houses came under suspicion. The brief discussion suggested a command of deep and complex interactions between prudential regulation and market making, which modern policy makers have (re?)discovered in the course of the subprime crisis.

${ }^{5}$ For more detailed discussions of the international dimensions of the London market see Clare (1891) and Rozenraad (1900).
} 
This makes the historical experience of the Bank of England as it was known or ought to have been known at the time when the Federal Reserve was created an important subject. This should shed light on how the European precedent shaped the US policy choices of the 1910s, and improve our knowledge of issues that are still relevant today. Indeed as we shall see, there is a fascinating parallel between the way the Bank of England found itself involved into rescuing a "shadow banking system" of non-bank, limited liability, money market institutions known as bill brokers (or perhaps more adequately "discount houses" although the two words were used interchangeably) despite its initial insistence on not supporting it because it saw it as a source of speculation and financial vulnerability. But when markets learned of the failure of Overend, Gurney, which the Bank had refused to help, liquidity seized and a violent panic set it. The Bank of England was forced to resume support to the shadow banking system. The analogy with the Fed's refusal to help Lehman in September 2008 and the events that followed is not only tempting: it is legitimate.

In effect the crisis of 1866 ended up being a turning point. As we argued in earlier joint research the adoption of a "modern" policy of "lending of last resort" (materialized by generous lending against good collateral) consolidated precisely at this time. ${ }^{6}$ The result was the adoption of "Bagehotian" principles for lending of last resort. These had been expounded in The Economist during the 1840s (before Bagehot's time) and then, with increasing assertiveness, during the 1860s, by Bagehot himself. These ideas came to be organized in Lombard Street, a book published in 1873. The book advocated generous liquidity support to the money market in periods of crisis. This begs for a greater research effort to provide for a better understanding of the how and why of this revolution. But it is fair to say that little recent work has been done to understand in finer detail the microeconomics of the Bank of England's lending of last resort. The way it selected bills, the way it protected itself against moral hazard, the way it monitored the market, and so on, are not really known - both qualitatively and quantitatively. ${ }^{7}$ We are not aware of any recent study providing an empirical exploration of the relations between the Bank of England and the London money market. ${ }^{8}$

As a result, older accounts still rule. They are of superior quality, and this per se has acted as an entry barrier. Classics include important works by historians who discussed in detail the operation of the money market and the Bank of England's relation to it (King 1936; Sayers 1936). Another important work is Sayers' (1968) account of Gilletts, a mid-size bill broker. Later research by Sayers (1976), Goodhart (1988) or Capie (2002) completes the picture. An important feature of the picture that emerges from this literature is the notion that, paramount in the transformation of the Bank of England into a modern central bank, was the development of "anonymous" dealing with the market. The Bank of England is usually portrayed as having managed to ignore the identity of borrowers as

\footnotetext{
${ }^{6}$ Bignon, Flandreau, and Ugolini (2011).

${ }^{7}$ This is in contrast with the situation for some other central banks of lesser international importance such as the Bank of Japan, for which recent econometric work is available (Okazaki 2007).

${ }^{8}$ Except for some investigations on the determinants of interest rate setting by the Bank of England such as Tullio and Wolters (2003a). For counterpart studies on the central banks of France, Germany, and AustriaHungary, see Tullio and Wolters (2003b, 2003c, and 2007 respectively).
} 
long as "good collateral" would be brought in for discount. Capie (2002) reflects this view in a powerful metaphor where he depicts the Bank's discount window as "made of frosted glass and raised just a few inches". In Forrest Capie's account, the central banker "does not know, nor does he care, who is on the other side of the window. He simply discounts good quality paper or lends on the basis of good collateral". ${ }^{9}$

These works are still outstanding, inspiring and they constitute our starting point. But some recent progresses in the availability of sources open new possibilities. We exploit here two types of ledgers that provide critical information on Bank of England crisis lending. First we use the ledgers for daily discounts, which record, as they occur, the succession of liquidity provision operations the Bank performed with counterparties. Second, we use the customers' ledgers, which were the instruments through which the Bank monitored its exposure to individual risks. As far as we know, neither the daily discounts ledgers nor customers' ledgers have been exploited systematically so far. The reason is that they involve accounts of private customers of the Bank, for which a full embargo used to apply, now shortened to a moving wall of one hundred years. ${ }^{10}$ Thus, while known to some previous scholars, this source could not be used as openly as we do it here. ${ }^{11}$

The tremendous value of such material is obvious. First, its very existence and the way it was organized suggests that there was more to the bank-discounter relation than the frost window metaphor would suggest. The bank kept detailed records, and monitored, the position of discounters (who presented the paper) and of acceptors (who had endorsed it). Second, this source enables to get an extremely detailed view on how the market operated. In principle, and subject to some limitations owing to partly missing sources for some dates and periods, a more or less complete characterization of the interactions between the Bank of England and the British money market throughout the succession of crises that occurred in England before the Federal Reserve Act - namely 1857, 1866, 1878,1890 , and 1907 would be feasible.

The present paper however, falls short of fulfilling such a vast scheme and sets itself a more limited intermediary target. First, the amount of work needed to master the enormous volume of information in the Bank's ledgers precludes a systematic study of all crises in just one paper. This explains this paper's focus on the Overend, Gurney panic of 1866, and if consolation is needed, it has been argued before, and we concur, that this crisis was a turning point. Second, working with the Bank ledgers cannot control for the self-selection involved in presenting given financial instruments to the discount

\footnotetext{
${ }^{9}$. Capie (2002), pp. 310-1.

10 . This rule has an effect on study of the 1907 crisis. Since some ledgers contain material covering the period after 1910 (and thus still embargoed), the Bank remains reluctant to communicate them today.

${ }^{11}$ An exception is Sayers (1968), who was shown by Bank of England archivists the entries for Gilletts in the Bank's "Brokers Ledger". Having been commissioned a history by Gilletts themselves, he had most probably been provided the needed clearance, thus releasing the Bank from its confidentiality duties towards customers. As a result, Sayers was able to document the episodes when Gilletts sought Bank of England support (as rarely as possible). Sayers (1968, pp. $55 \mathrm{ff}$ ) also notes that his Bank of England Operations "had not the benefit of access to the Bank's records, but fits tolerably well with Gilletts' transactions at the Bank, inspection of which has now graciously been allowed by the Bank".
} 
window. The view we give of the money market must by construction be partial, and the only defense is that the central bank's perspective to the matter remains crucial and that future research ought to provide further scrutiny of our main findings.

The methodology in this paper is the following. We provide a statistical exploration of the financial instruments the Bank of England purchased during May 1866 (the month when the so-called Overend, Gurney crisis of 1866 peaked) and compare it with a "normal" month exactly one year earlier (May 1865). By combining these two pictures ("normal" and "crisis time"), we seek to understand better the changeover that occurred either in the type of instrument or of the type of customer. There are four key findings. First, we unearth a rich system of monitoring by the Bank of England, which suggests that its approach to the money market was probably less anonymous than implied by earlier accounts. Second we discover the considerable importance of the non-bank counterparties for the Bank of England's operation during crisis periods. This can be put in relation with the importance of the present shadow banking system and the way the central bank can end up being hostage of financial innovation. ${ }^{12}$ Third, we discover that more than two thirds of the bills discounted at the Bank's window had been originated abroad, i.e. had been issued by foreign correspondents of British banks. It is a striking feature that the staple instrument for the conduct of British monetary policy and crisis lending was related to foreign trade. We also find that the surge of foreign acceptances as the staple instrument of monetary policy was a development of period 1850-1870. Last, we emphasize the importance of central bank's supervision and prudential role in fostering the liquidity of certain instruments. We argue that "trade acceptances" were convenient instruments to supervise and this is why they ended up as the chief support for liquidity provision. This suggests that the root of the special status of sterling was not solely Britain's predominance international trade but Bank of England's advance in supervision.

The remainder of the paper is organized as follows. Section I reviews our new source in relation to the operation of the money market. Section II explores the rise of the "shadow banking" system in England until the crisis of 1866. Section III looks at who came to secure cash in 1865 and 1866. Section IV explores what was brought in. Section V deals with the question of central bank supervision. We end with conclusions.

\section{Section I. The London Money Market and Bank of England's Ledgers}

Conventional descriptions of the set of instruments comprised under the heading "British money market" traditionally emphasize the role of acceptances. Acceptances were bills that one merchant or banker (the drawer) had drawn on another merchant or banker (the drawee) and that the drawee had "accepted" by putting his signature on the bill. Prestigious drawees were leaders in the acceptance business and sold their signature for a fee. Previous literature has emphasized the role of "merchant banks" but also of some British foreign and colonial banks as key providers of acceptances, and

\footnotetext{
${ }^{12}$. On the shadow banking system, see Gorton (2010).
} 
mention the presence of some private and joint-stock banks although their importance is said to have only started much later (Jenks 1927; Chapman 1984). From that point, conventional accounts suggest, flowed a kind of "circuit" whereby the acceptances (initially supplied by correspondents of leading British merchant banks and then certified by those very merchant banks) were purchased, through the agency of bill brokers, by large commercial banks, for reserve purposes. As time passed, bill brokers started to get invested in these acceptances for their own account, using resources they collected through "call loans" (essentially, time deposits) from the commercial banks. The result was that they gradually evolved into money market funds. In case of crisis, commercial banks would secure liquidity by going to the Bank of England, re-discounting the acceptances they held, and get cash in return. In addition, they would call back their deposits with the bill brokers who, in order to meet the cash requirements of the commercial banks, would in turn have to unwind their own balance-sheets by discounting bills with the Bank of England. ${ }^{13}$

While this description will receive qualification later on, it has a heuristic value as a starting point. It helps understand that the Bank of England's discount window was a bit like the pond in the savannah - the place where the wild beasts of the money market come to water. Data pertaining to what was happening at the discount window has rich informational value. In this paper we exploit information on the London ledgers of the Bank of England, in order to provide a detailed picture of the Bank's lending of last resort activities.

There were two different ways in which the Bank of England provided cash to customers. The first one, called "discounts", consisted of an outright purchase of acceptances. The second one, known as "advances", amounted to a modern repo operation: the Bank took in bills or bundles of bills ("parcels"), but the counterparty was understood to repurchase the security from the Bank at a given date. Advances were secured by the security given in repo, to which a haircut was added. As decades passed, the number of securities eligible for advances increased ${ }^{14}$ but for the period under study, advances could be made on acceptances, on domestic sovereign stock such as Consols (for "Consolidated", as British government bonds were known), or on Indian government bonds. ${ }^{15}$ Bank of England discounts, on the other hand, were exclusively based on acceptances, and were secured by the signature of both the discounter and the acceptor.

\footnotetext{
13. Withers' report for the National Monetary Commission, (Withers 1910, pp. 53-55) is thus characteristic when it emphasizes that the business of acceptance is "largely in the hands of the leaders among the old merchant firms, whose acceptance of a bill stamps it at once as a readily negotiable instrument" and states later on (Withers 1910, p. 61) that "the discount houses in London carry on a business that is chiefly ancillary to that of the banks".

${ }^{14}$. Although the practice of doing advances on securities goes back to the $18^{\text {th }}$ century (Clapham 1944), the statistical separation between "discounts" and "advances" is not available for early times. C30/3 only gives the breakdown from 1853 onwards.

15 . Bagehot (1873) complained that railway bonds ought to have been included as well. At the time of the National Monetary Commission, these included all securities traded on the London Stock Exchange except those relating to mining companies (highly speculative: Aldrich 1910, p. 20).
} 
Not anybody could come at the Bank of England's window. The Bank had a list of eligible discounters. In London (on which we focus here) discounters could be any kind of firm involved in "trading" (i.e. commerce or industry), merchant banks, commercial banks, and bill brokers. To become eligible, one had to be recommended by some authority and the so-called "rating books" bear mention of the authority that had provided recommendation (often a senior merchant bank or a bank director). ${ }^{16}$ There were 438 discounters in 1865,503 in $1866 .{ }^{17}$

The Bank kept a record of discounters approaching it for cash procurement, regardless of whether it agreed or not to the loan (in the overwhelming majority of cases it did), and then when it agreed to the operation, several entries were created according to a very meticulous system, bearing witness of a careful monitoring of risks and exposure by the Bank of England. First, there was a Bank of England's window's journal. Day after day the so-called "daily discounts" ledger entered individual discounters" applications as they came. Table 1, reproducing the entry for May $3^{\text {rd }}, 1866$ shows (See Figure A.1 in Appendix for picture of original), shows the information recorded in this ledger. It included the number of bills brought in for discount by individual discounters, the rate, the name of the discounter benefiting from the discount or advance, the amounts discounted or advanced, the number and amount of bills rejected if relevant, and a "remarks" column that could be used to give reasons for rejecting applications. In the example displayed, reasons for rejecting a bill included "sighting altered" (suggesting a poor-looking bill, perhaps a forgery) and "beyond 95 days" (usually the Bank restricted its discounting to bills with less than three months to run). ${ }^{18}$

Consistently with the evidence in the "rating books", the Bank also controlled its exposure on a per-customer basis. Every operation (discount or advance) was reported in individual accounts in ledgers which were organized by institutional types - as we explain below. Because the discounting of bills was secured by both the acceptor's and the discounter's signatures, two entries were created each time a bill was taken in: one in the discounter's account and the other in the acceptor's. Ledgers were manifestly used to monitor "at a glance" the position of customers: they did show, for each entity, the outstanding amount of credit guaranteed either as a discounter or as an acceptor.

Table 2 shows the entry for one random merchant bank and date (Smith Fleming \& Co., $11^{\text {th }}$ to $17^{\text {th }}$ May 1866). As can be seen, for each liquidity provision event the ledger documents several characteristics: the place where the drawer of the bill (if the event involved a bill) was located ( $1^{\text {st }}$ column), his name ( $2^{\text {nd }}$ column), the date of the liquidity provision event ( $3^{\text {rd }}$ column), a reference to the other page in which the same operation was recorded $\left(4^{\text {th }}\right.$ column $)$, the name of the "other

\footnotetext{
${ }^{16}$. These are found in ledgers from the discount office archive, bearing the title: "Rating books, showing each discounter's credit limit". These handwritten "rating books" were updated when needed and bore many corrections until a wholly new rating book was issued and in turn updated, corrected etc.

${ }^{17}$. BoE Archive C30/3. The source does not tell whether the number corresponds to eligible discounters or those of the eligible discounters who sought discounts from the Bank, although we suspect the former to be the case.

${ }^{18}$. The "daily discounts" ledgers also contain convenient monthly and yearly recapitulations, with some useful totals, such as the aggregate value of applications received, rejected, a breakdown of advance and discounts, and occasionally, some additional evidence such as the breakdown between bills drawn by a domestic bank or by one located abroad and known respectively as "inland" and "foreign" bills.
} 
signature involved" (i.e. the name of the acceptor if Smith Fleming \& Co. was the borrower, or the name of the borrower if Smith was the acceptor) ( $5^{\text {th }}$ column), the maturity $\left(6^{\text {th }}\right.$ column), and the amount of credit granted by each operation registered in the relevant column in the last group. ${ }^{19}$ As it can be seen, the Bank could constantly monitor customers. If need be it could at any time measure its exposure to any single entity.

As said, the Bank did recognize differences among customers and this motivated the use of different ledgers. The "discounters" ledger (as the Bank called it) included predominantly merchant banks and trading houses, such as Smith Fleming \& Co. It was a mixed bag by nature: merchant bankers being heavily involved in international commodity trade, the line separating "traders" and "merchants" was thin. In the beginning, all customers of the Bank were included in this one ledger but, as specialization increased in the money market, some classes of customers were given special ledgers. "Bill brokers" had their own. Under this item were found a variety (though not all) of a number of money market funds variously known as "bill brokers", "discount houses", "discount brokers" or "credit companies". ${ }^{20}$ Yet another group, the "bankers", initially included in the bill brokers ledgers, came to have a ledger of its own (in 1864). ${ }^{21}$ These were joint-stock such as the London Joint-Stock Bank, or private such as Glyn Mills Currie \& Co. They could be located in London (such as the ones mentioned above), in the rest of the Kingdom (such as the Royal Bank of Liverpool), in colonies (such as the Union Bank of Australia), or abroad (such as the Imperial Ottoman Bank), provided they had a London branch. ${ }^{22}$ Finally, there were discounted bills that had not been drawn on customers of the Bank (probably because the guarantees offered by the discounters were considered as sufficient). These were recorded in the so-called "upon ledgers". Taken together, these ledgers covered all the material that was taken to the Bank.

\section{The Shadow Banking System and the Crisis of 1866}

As noted earlier, Withers (1910) called the bill brokers "ancillary". They are the Cinderella of the reports to the National Monetary Commission, perhaps because, by the late $19^{\text {th }}$ century, they had

\footnotetext{
${ }^{19}$ That is, in the "With" column if Smith Fleming \& Co. was the borrower, and "Upon" if it was the acceptor, controlling for whether the operation was a discount or advance. "Advances Upon" corresponded to a repo contracted by another customer on bills accepted by Smith.

${ }^{20}$ Adding up the entries in the Bank of England ledgers, we find 57 "bill brokers", a subset of which only operated in 1865-66. The Bankers' Almanac of 1866 does distinguish between "recognized discount brokers" (i.e. private houses such as Alexanders Cunliffes \& Co) and "principal discount and credit companies" (i.e. jointstock structures that operated as money market funds). All of the Almanac's "recognized discount brokers" are listed in the Bank's ledgers. But the Bank of England's bill brokers ledgers has also a large list of private bill brokers not found in the Bankers' Almanac of that year. Conversely, only 7 of the 19 "principal discount and credit companies" in the Almanac are in the Bank's ledgers (implying that they did not have a discount account). ${ }^{21}$ Before that date they were included in the bill brokers ledgers.

${ }^{22}$ For completeness we should mention the "Drawing Office discounters", which included a variety of merchant banks and other trading houses that used to be customers on a regular basis and were thus allowed to have a current account opened at the Bank. Within these commercial customers we find bullion dealers and refining houses, industrial concerns such as shipbrokers, brewers, linen factors, but also the Crown Agents for the Colonies. For practical purposes, in this study, we decided to aggregate this category to the "merchant banks and trading houses" one.
} 
managed to become such a perfectly integrated part of the money market machinery that they could go unnoticed. Yet their importance never escaped the attention of the best connoisseurs of the London money market (King 1935, 1936; Sayers 1968). King $(1935,1936)$ has strongly emphasized the role of bill brokers in promoting the market for acceptances in the first half of the $19^{\text {th }}$ century. These were started as private finance companies, with unlimited liability, and essentially matched the supply and demand of bills. As funds do, they looked for safe instruments with higher returns (for instance because they came from initially segmented markets) and leveraged (King 1935). According to King (1936) bill brokers flourished after the 1825 crisis, when complete illiquidity of the inter-bank acceptance market caused by rampant credit rationing pushed many London-based commercial banks to bankruptcy. ${ }^{23}$ Survivor banks would have pledged never to experience such a situation anymore, and stopped holding their liquid resources in bills. This created the opportunity for bill brokers to transform into money market funds: they gradually came to attract on-call deposits from commercial banks, which they reinvested in the acceptance market. ${ }^{24}$ To put it differently, bill brokers would have emerged because of their willingness to bear the risk of balance-sheet mismatches - which commercial banks were no longer ready to do. In the 1840s two private firms, Overend-Gurney and Alexanders, stood as leaders of this industry. They had very large credibility and are generally described as having captured an increasing market share (see King 1935 for crude mid-century estimates). The resulting leverage, which was increased over time, boosted returns (King 1936 gives ratio of capital to deposits as 1 to $10-15$ in 1847 and rising). Partners had the reputation to have amassed "fabulous fortunes". 25

In a first stage the development of bill brokers is said to have been supported by the Bank of England. The growth of the money market in London occurred when the Bank of England permitted certain chosen bill brokers to open discount accounts. ${ }^{26}$ When the brokers sought liquidity, they could go to Threadneedle Street and found the Bank ready to discount the bills of exchange they held. ${ }^{27}$ Several authors have described the relation between the Bank of England and the bill brokers as symbiotic. There were constant exchanges between leaders of the industry and the Bank. Another theme we find in the literature is the role of bill brokers as a transmission mechanism for monetary policy. The bill brokers had large, leveraged inventories and tended to suffer when the Bank rate rose, because liquidation then occurred at a loss. According to Sayers (1968), a sudden hike in the Bank of England's rate could easily wipe out one year's profits. As a result, when a Bank rate increase was in sight, bill brokers covered themselves by pushing interest rates in the open market, thus making the Bank rate effective ahead of actual changes. ${ }^{28}$

\footnotetext{
${ }^{23}$ See Bignon et al. (2011) for evidence on the surge of defaults during the crisis of 1825 and a discussion of preBagehotian credit rationing technique.

${ }^{24}$ King (1936, pp. 62-70).

${ }^{25}$ Bankers' Magazine about Samuel Gurney, quoted in King (1936, p. 217).

${ }^{26}$. See King (1936, pp. 68-69 and 89-90) as well as Clapham (1944, Vol. II, p. 142).

27 . Focusing on the 1830 s, Tamaki (1974) describes a system whereby bills drawn by US correspondents on Barings could be invested upon by Gurney \& Co, who could in case get refinanced at the Bank of England.

28 . This was even recognized by Withers (1910, p. 63).
} 
Because of the deep structural changes dictated by Peel's Act, however, an adversarial relation developed after 1844, and further deteriorated with the 1857 crisis. As the subsequent Parliamentary Committee pointed out, the Bank found that, during the crisis, about $36 \%$ of London advances had been made to bill brokers "partly upon securities which, under other circumstances, the Bank would have been unwilling to accept". ${ }^{29}$ This large number contrasted with the smaller figures that were observed in normal times, when bill brokers tried to minimize their refinancing and reserves at the Bank of England. ${ }^{30}$ The Bank decided that the brokers were free riding on the Bank's window. This concern, according to Bagehot (1873) and to a number of other contemporary and subsequent writers, was amplified by the directors' preoccupation with profitability. The Bank would have suffered from brokers' competition and was thus less and less willing to help them out in difficult times. Insurance they would be bailed out by the Bank, it was argued, made them even more aggressive in normal times. As a result, in March 1858 the Bank inaugurated a new rule that banned bill brokers from discounts and, practically, advances too. ${ }^{31}$ Support in crisis times was not excluded, but the Bank would see.

This led to an era of conflicting relations, and King has argued that the "sixties therefore, were marked by a pronounced lack of co-operation between the Bank and the bill market". ${ }^{32}$ Verbal threats and retaliatory moves followed. The Bank was said to be discriminating against bill brokers. The heart of the confrontation was with the leading discount house (Overend-Gurney). In 1860, in an act of defiance, Overend suddenly withdrew from their account at the Bank "no less than $£ 1,650,000$ all in $£ 1,000$ notes". The Bank had no other solution than to raise brutally the interest rates, causing chaos in the money market. ${ }^{33}$ De facto, this put an end to the relationship between the Bank and Overend: despite still showing up in the list of agreed discounters, the bill broker ceased to rely on the Bank's rediscounting facilities in the following years. ${ }^{34}$ The events of 1866 were a direct consequence of this situation.

The full story of the money market during that period remains to be written. An issue that emerges clearly from earlier accounts is that the Bank was preoccupied with what we would call today

\footnotetext{
${ }^{29}$. See King 1936, p. 200, who relies on the report of the Select Committee on the Operation of the Bank Act 1858.

30. They earned money from leverage and the difference between the lending rate and the rate at which they secured funds, so any balance at the Bank of England or rediscount there was a loss of money.

31 . King (1936). Only a lifeline to advances routinely made during "shuttings" (i.e. when dividends on British debts were paid) was maintained. The text of the March 1858 decision in the Bank of England Archive, which Charles Calomiris kindly communicated to us read: "that habitual advances by Discount or Loan to Bill Brokers, Discount Companies and Money Dealers being calculated to lead them to rely on the assistance of the Bank of England for their security in time of pressure; Advances to Bill Brokers, Discount Companies and Money Dealers shall be confined to Loans made at the period of the Quarterly Advances [shuttings] or to Loans made under special and urgent circumstances which shall be communicated by the Governors at the earliest opportunity to the Court for its approval".

${ }^{32}$. King (1936, p. 216).

${ }^{33}$. This was abundantly discussed in the contemporary press. See the famous discussion in Bagehot (1873). See King (1936, p. 213) for details.

34 . Bank of England Archive, C25/3 and C24/1.
} 
supervisory and prudential issues. The decade from the mid-1850s saw the expansion of international trade and the increased role of British capital in funding it. The liquidity of the London market gave it a competitive edge for both imports and exports. Reflecting the initial illiquidity of a number of trading niches, merchant banks moving into trade acceptances secured large commissions, which they could get without immobilizing any resource, provided that there were ready buyers for the bills. ${ }^{35}$ Continental merchant bankers moved to London to avail themselves of these enormous benefits and joint stock banks with an international orientation were created in the $1860 \mathrm{~s}^{36}$

Attracted by the fortunes of the early leaders in the field, and pushed by the resulting supply of bills, which looked for holders, money market vehicles were created in the form of joint stock discount companies that took advantage of the new limited liability law. Several companies were created -- the London Discount, the National Discount, the Joint Stock Discount, or later the Discount Corporation, the Consolidated Discount Company, the Mercantile Discount Company, or the Financial Discount Company. Just like modern money market funds, they were supposed to invest in blue chip bills but often ended up attempting to boost returns by taking more risk onboard - in the familiar way: they invested in illiquid securities. It was also said that their limited liability setup made them less vigilant than their private predecessors. There were suggestions of "questionable operations" and adventures in "paper that [...] should not have [been] touched". ${ }^{37}$ Allegations were made that weakening in investing standards facilitated dubious forms of origination. These included "finance" or "accommodation bills" whereby a firm asked a correspondent to draw on itself without real counterpart transaction, the employment of agents to push the bills into discount houses, the creation of a circulation of fictitious credit among networks of suppliers, or the mortgaging of bills with long maturities (which amounted to securing the bill not by a real security, but by another one).

Overend Gurney \& Co. had the misfortune to buck the trend. While previously known as a standard of prudence concerned with "setting its face" against questionable practices, it developed during 1855-65 into something that looked more like a financial conglomerate. Successive failures of companies whose bills it had subscribed led it to end up with industrial assets, which it tried to run for its own account. At one point, Overend owned two miniature fleets that had belonged to Anglo-Greek merchants. The firm was also heavily invested in railway shares and other industrial securities, thus essentially becoming a universal bank. In what shareholders later described as a last ditch attempt to hide its collapse (but judges, and King 1936, disagreed), the firm finally transformed itself into a limited liability company. The stock market collapse of late 1865 and early 1866 battered the company's balance-sheet. Failure of a number of customers forced Overends into further losses. The Bank of England was approached but the "Governor took the view that the Bank could not assist one

\footnotetext{
35 . For instance, Roberts (1991, pp. 527-537) reports figures suggesting that fees on acceptances (which involved no immobilization of capital provided that bills could be readily sold) were as large as $1.5 \%$ in the early $1860 \mathrm{~s}$. This large number is consistent with figures for commissions, which are said to have varied from $0.5 \%$ to $1.5 \%$ and shows how specialization in a new market could put a merchant bank close to the upper bracket.

${ }^{36}$. See King (1936, pp. 176-7).

37 . King (1936, p. 228).
} 
concern unless it was prepared to also assist the many others which were known to be in similar plight". ${ }^{38}$ This was decided after a confidential report was commissioned to investigate whether assistance by the Bank or a consortium of London commercial banks was merited. Desperate calls to other bankers were unsuccessful and at 3:30 p.m., May $10^{\text {th }}, 1866$, Overend Gurney \& Co. suspended payment.

The result (10 and $11^{\text {th }}$ May) was the "wildest panic": contemporaries compared the event with an "earthquake", and King (1936) writes that it is "impossible to describe the terror and anxiety which took possession of men's minds for the remainder of that and the whole of the succeeding day". ${ }^{39}$ Markets seized, all transactions were suspended. The financial system grind to a halt and the only thing people wanted was Bank of England notes or bullion. Several banks and discount houses stopped payments or came close to it. Meanwhile, the Bank met all "legitimate" demands, lent over $£ 4$ millions in one day while its reserve fell by close to $£ 3$ millions. Then the Governors sought from the Treasury the permission to infringe the Bank Act (suspend convertibility), obtained it, raised the Bank rate further and stood ready to provide massive relief. As in previous crises, "suspension" of the Peel Act was the signal for the panic to subside.

\section{Section III. Credit in Ebb and Flow: Who Came?}

The evidence we constructed in this article is destined to help understand better the lending policy of the Bank of England during the crisis of 1866. In this section we begin our foray by documenting the profile and needs of those who came to the Bank of England to get cash. We work with the daily discount ledgers, and identify both volumes and the identity of those who came to secure cash. Because the Bank worried with customers' types, such information is available in the ledgers.

Figure 1a and b show daily (nominal) amounts sought for in either discounts or advances, as well as the amounts rejected for each category, in May 1865 and 1866 respectively (each business day is represented as a bar). As can be seen, lending literally exploded on May 11 when the suspension of the Act was granted to the Bank of England. As a result, the crisis month (May 1866) was characterized by much larger amounts of cash supplied compared to the normal month (May 1865). The share of rejected bills was also reduced in May 1866 compared to its 1865 counterpart. This is suggestive of an extensive role of the Bank of England to support the market. Last, we see that discounts predominated during both periods, but the relative share of advances increased markedly during the crisis and neared half of the amounts provided in the peak of the crisis. The implication is that in crisis times the range of instruments supplied and accepted by the Bank was broadened as people desperately sought to provide adequate collateral in exchange for cash.

\footnotetext{
38 . King (1936, p. 242).

${ }^{39}$. King (1936, p. 243).
} 
The next figures decompose the amounts distributed in discounts (Figure 2a and b) and advances (Figure 3a and $\mathrm{b}$ ) according to the "institutional" categories identified above. We separate amounts received by bill brokers, bankers, and "ordinary" discounters (which mix together merchant bank and other "trading houses"). Let's begin with discounts (Figure 2a and b). The crisis saw a dramatic transformation in the identity of those who came in. While bill brokers and bankers were virtually absent in 1865 , they became very important customers during the crisis. A similar pattern is observed for advances: again banks and bill brokers represent a large share of the amounts advanced during the crisis (Figure $3 \mathrm{a}$ and $\mathrm{b}){ }^{40}$

The reasons for the changeover in the position of bill brokers and banks is of course natural in view of what we said earlier: banks faced the risk of a run of depositors, and sought to increase their cash holdings. This was secured at a lower rate on the inter-bank market, but in case of a panic this market froze and the only options they had were either going to the Bank or withdrawing their on-call deposits from the bill brokers. Bill brokers, who managed their portfolio of bills with resources from the banking sector, had to meet the banks' cash withdrawals. The Bank of England then became the natural counterparty in a vanishing market. There was just nowhere else to go, explaining why the Bank had to support the market and why, in such instances, it could always expect to benefit from a suspension of the Bank Act - as this was the only way to backstop the market. Figure 5b suggests why the Bank's anti-bill-brokers rhetoric started in 1858 was immediately put to rest when the crisis hit: the share of bill brokers in advances made in London during the crisis of 1866 is of the same order of magnitude as the one that had been observed during the crisis of 1857. The Bank of England may have had normal times' customers, loyalties, and preferences. But in a crisis it was just impossible to escape the responsibilities laid on its shoulders by the community (and encapsulated in "suspensions" of the Bank Act, granted by the Treasury). While it could continue to tender to its regular customers in difficult times (and we see that discounts and advances to merchant banks and trading houses increased as well), it was also bound to enlarge the scale and scope of its liquidity provision operation.

To deepen our foray, we now take a look at the characteristics of the population of customers who came to the Bank's window in 1865 and 1866 to get discounts or advances. This we do by collecting data from the daily discounts ledgers. The results are organized, not on a discount event basis, but on a discounter basis: this means that in case a discounter came several times during that month, we use the total of all discounts made with that customer for that month. As can be seen in Table 3a, there were 269 customers who came to the Bank in May 1865 to get discounts, and 372 in May 1866 (representing respectively $61 \%$ and $74 \%$ of the Bank's eligible discounters for the respective years). ${ }^{41}$ Customers asked for widely varied amounts of cash, ranging from $£ 30$ to more than $£ 100,000$ in 1865 ,

\footnotetext{
${ }^{40}$. In aggregate numbers for the entire two months, bill brokers and bankers represent respectively $0 \%$ and $2 \%$ of the total discounts and advances in 1865 , but $21 \%$ and $33 \%$ in 1866 .

${ }^{41}$. The year 1866 saw an upsurge in the number of customers, possibly because the crisis led to an increase in applications. These numbers we compute under the already mentioned assumption that data in $\mathrm{C} 30 / 3$ relate to the number of eligible discounters, not to the number of applicants.
} 
and from $£ 43.81$ to $£ 692,520$ in 1866 . Reflecting this increase in maximum amounts required, the mean also shot up from about $£ 8,000$ to about $£ 27,000$ and the median also rose (from about $£ 3,700$ to about $£ 5,200$ ). Similar features are observed for the advances, which are reported in Table $3 \mathrm{~b}$.

A nice way to capture what was going on is to construct "Pareto curves" of the demand for discounts and advances during the two periods. This is done in figure $6 \mathrm{a}$ and $\mathrm{b}$. While in 1866 the $20 \%$ largest discounters received $80 \%$ of the cash dispensed by the Bank of England (the Pareto rule!), in 1865 the proportion had been only $65 \%$ (Figure $4 \mathrm{a}$ ). A similar pattern is observed for advances: the $20 \%$ largest receivers of advances secured above $75 \%$ of totals in 1866 but only about $60 \%$ in 1865 (Figure 4b). Another way to put it is to note that the top three discounters received $13 \%$ of the total in 1865 , but $18 \%$ in 1866 . Respective numbers for the top ten are $30 \%$ and $36 \%$. In other words, the distribution of funds was more unequal during crises. This is consistent with the view that there was more "commercial lending" in normal times, while during crises generous lending to the needy predominated. Last, we also note that this "concentration" of lending should not obfuscate the fact that lending remained quite scattered: the number of institutions receiving significant amounts was not modest (there were more recipients in 1866 than 1865, we found). In other words, central bank lending in crises was both extensive (more aggregate lending to all) and intensive (more relative lending to some).

Of course, in view of the previous finding that the crisis was also characterized by the emergence of certain customers, it is tempting to argue that the reason for the increase in inequality was the arrival at the Bank's window of cash-hungry financial intermediaries who sought to secure large amounts of refinancing. To explore this, we delve further in the data and take a look at the identity of the top discounters and recipients of advances. Figures $5 \mathrm{a}$ and $\mathrm{b}$ and $6 \mathrm{a}$ and $\mathrm{b}$ show "market shares" (shares in total amounts during the relevant months) of the top fifty institutions receiving the biggest amounts of discounts and advances in May 1865 and May 1866 respectively. As can be seen, the evidence fully confirms the impression from earlier Figures. The increase in the share of bill brokers and commercial banks during the crisis, as well as the rise of Gini coefficients, does reflect the arrival of a limited number of customers who asked for (and received) generous credit. In 1865, the top three discounters belonged to the "merchant banks and trading houses" category. ${ }^{42}$ In 1866 however, the top three, for much bigger amounts, were two leading bill brokers (private Alexanders Cunliffes \& Co., and joint-stock National Discount Co.) and one private commercial bank (Barclay \& Co.). A very similar phenomenon occurs for advances. There again, "merchant banks and trading houses" dominated in 1865 , while bill brokers and commercial banks led the way in $1866 .{ }^{43}$

\footnotetext{
42. Bischoffsheim \& Goldschmidt, Cavan Lubbock \& Co., Frith Sands \& Co.: these merchant banks had, respectively, connections with Continental Europe, Canada, and India.

43. An interesting feature is the greater lead by banks compared to bill brokers in advances. This seems to confirm the above-mentioned preference of commercial banks for not discounting bills directly on the market. It may be that, as banks were competing against the Bank of England for commercial credit, they were reluctant to reveal private information by discounting their own paper. In any case, this issue should receive more attention in the future especially since it has been argued that (albeit for a larger period) the Bank of England really
} 
We conclude by emphasizing that the increase in the concentration of discounts during crises was due to the sudden arrival of big requests from institutions that were not regular customers of the Bank - financial intermediaries facing liquidity shocks. In crisis mode, Bank of England lending did continue to service the London traders and merchants. ${ }^{44}$ But their requests were dwarfed by the support granted to London "financial Gibraltars" - both banks and "shadow banks", which the Bank was prepared to shore up in what it saw as "urgent circumstances".

\section{Section IV. Discounting in Ebb and Flow: What Did They Bring In?}

Next, we study what discounters did bring in. This means opening the black box of the money market and getting an understanding of the types of instruments that were allowed to flow freely from the market to the Bank. Data limitation imposes to narrow down the focus of our study to the geography of bills discounted. We thus exclude securities pledged as collateral for advances. ${ }^{45}$ Given the statistical importance of discounts, this should nonetheless provide relevant information. Addressing this question breaks new ground. We are not aware of any related previous attempt to uncover the nature of the material traded in the London money market, apart from the discussion by Sayers (1968) of the portfolio of a junior bill broker (Gilletts) at two benchmark dates. Most available evidence we are aware of is qualitative. ${ }^{46}$

Ideally, one would want to get some idea of the "risks" associated with the categories of paper that were taken by the bank. However, for lack of independent, "rating like" assessment of the bills, we are bound to circumnavigate the issue a bit and find indirect ways to approach the contours of eligible instruments. Three questions will guide our discussion. First, we are interested in knowing the respective proportion of domestic vs. foreign bills taken by the Bank. The reason is that the expansion in discount houses was related to the increase in international trade: it would be interesting to know the extent to which the Bank did support this trend in the market. ${ }^{47}$ Second, we are interested in the identity of the acceptors, and in particular in knowing whether the crisis led to distortion in the type of

discriminated against advances. Wither (Withers 1910, pp. 6-7) argues that at the time of his writing a customer "taking advances on securities [...] usually pays one-half of 1 per cent above Bank [discount] rate" which applied to bills.

${ }^{44}$. The large presence of Bischoffsheim \& Goldschmidt at a time of active international bullion arbitrage reflects the use by some merchant banks of central bank facilities to conduct their operations (Flandreau 2004). Ugolini (2011) discusses Bischoffsheims' emergence as leading international merchant bankers.

${ }^{45}$. As shown by Figure 2, advances are not systematically documented by our sources. This is because some material was made of bundle of bills called "parcels" that were "unpacked" in statistics (except concerning the identity of acceptors), while other securities than bills are not documented.

46. Such as the discussion in Bagehot (1873) that during the 1825 crises "anything" had been brought to the Bank.

47 . This would also have independent value for discussion of the aggregate supply of inland and foreign bills. This matter is not well-known. King (1936, p. 271) argues without quoting numbers that "the decline [of the inland bill at the expenses of foreign bills] may be said to have begun shortly after the 1857 crisis, although it was not until the "seventies that it became at all marked". Later scholars have argued that the growth in the use of foreign bills as opposed to inland bills was a later phenomenon, tied to the "amalgamation movement" in British banking of the late $19^{\text {th }}$ century (Nishimura 1971). 
paper that was brought in. Earlier accounts such as Chapman (1984) suggest that the market for acceptances was very concentrated, reflecting the quality of a limited number of signatures. ${ }^{48}$ One interesting issue would be to determine whether the Bank of England delegated to prestigious acceptors the responsibility for screening the bills (in which case it would tend to concentrate its discounts on a few high prestige signatures), or whether instead it sought to diversify its exposure (in which case we would expect the Bank to buy bills endorsed by many different acceptors). Third, we are also interested in knowing more about the geography of sterling acceptances. In particular, we would like to test whether it reflected British trade patterns. To the extent that acceptances were predominantly created through the infrastructure of trade finance, we expect Bank of England's material to have reflected underlying opportunities (trade shares), provided that the Bank did support the new tendencies in an undiscriminating way.

As discussed in Section I, the location of the drawer and thus the geographical origin of the bill was documented in the customers' ledgers: in Smith Fleming \& Co.'s account shown in Table 2, we see that discounted bills had been drawn from places like Bombay, Shanghai, Montevideo, etc. As a result, it is possible to reconstruct most of the geographical origin of the bills. Provided that a proper sample is constructed, we should in principle be able provide answers to the questions we raised. In what follows, we exploit information for two separate samples, corresponding to the portfolio of bills discounted by the "top discounters" and "top acceptors" respectively. ${ }^{49}$

\section{a) The Inland/Foreign Split}

We begin with the inland/foreign split of Bank of England's discounts. That is we document the share of the value of bills drawn from abroad in the value of total discounts by the Bank of England. Using both the "top discounters" and "top acceptors" we found that the share of foreign bills was huge

\footnotetext{
48. There is disagreement, however, as to when this concentration occurred. King (1936, pp. 280-281) suggests that this only occurred after 1870 . He argues that other banks (private and joint-stock) were also active in the market of acceptances, but less so - and only later in the century. Chapman (1984, pp. 39-41) believes in a fairly early concentration of the market for acceptances (as early as in the 1830s). A conventional view in previous work is that when the amalgamation movement occurred in the 1890s, the giant clearing banks also became large suppliers of acceptances - although here again it is usually said that merchant banks' material still reigned supreme.

49 . Covering the whole material discounted by the Bank not being practical, we constructed two "samples" that were used to address, either simultaneously or separately, different sets of questions. The first sample uses information obtained from the material brought in by the "top discounters" (for both May 1865 and May 1866) as emerging from the "daily discounts" ledgers. Since we collected whole the material for daily discounts we do know the league tables for top discounters and this is how the sample was constructed. However, given the modification in the identity of those who came to the Bank of England, this means that the ranking of "top discounters" changes a lot between the two periods. The second sample, was captured through a field technique which amounted to collecting the accounts that had, on an eyeball test, "substantial length" (viz. entries with several pages). We called it "top acceptors" for simplicity, but it should be emphasized that we do not know the actual ranking of "top acceptors" which were not sorted out by the Bank in any way that would permit collection of this information. An interesting test of consistency between the two samples is to match estimated acceptors market shares acceptors according to their "random drawing" from information about to discounters, with the information on their exact market share from exploring acceptors' data. This enabled us to draw some suggestive charts.d
} 
in 1865 and 1866. The percentage of foreign bills is $85 \%$ in 1865 and $63 \%$ in 1866 . With the "top acceptors" sample, the proportions are $89 \%$ and $86 \%$ respectively. Beyond the difference across samples discussed below, the evidence provides strong supportive evidence for the foreign orientation of the prime material traded in the London money market (and thus willingly taken in by the Bank).

For comparison, some relevant archival material is available for the early $19^{\text {th }}$ century. We also found a number of totals computed by the Bank of England itself and reported in the last pages of the Annual Volumes for the Daily Discounts $(1854,1855,1856$, and 1859). Table 4 summarizes the evidence and bears witness of a drastic progression in the share of foreign bills compared to the beginning of the century and accelerating during the late 1850s and early 1860 s. Does it mean that the Bank of England modified its behavior, or instead was the composition of originated sterling bills being modified? Figure 7, looks at this by comparing the share of foreign bills within the Bank's discounts with the share of foreign bills within the whole British acceptance market during the $1850 \mathrm{~s} .{ }^{50}$ As can be seen, the two lines are parallel, with Bank's portfolio ahead of the entire domestic market in terms of exposure towards international bills - a natural outcome, given Bank of England's relationship with London-based, more internationally-oriented, intermediaries. The suggestion therefore is that the evolution of the material taken by the Bank of England reflected global trends (although data for the 1860 s would be useful too). To conclude, the data emphasize that the development of lending of last resort operations was intrinsically related to the growth of trade finance. And if stories that the growth of discount companies was motivated by the concern with taking advantage of expanding trade finance are to be taken at face value, we are bound to conclude that the Bank of England bucked the trend.

The second interesting feature from our data is the fact that during the crisis of 1866 , the relative share of foreign bills in the discounters' sample declined (but their total increased a lot). Top acceptors in the London market were specialists in foreign bills unlikely to change their specialization in the event of a crisis. Therefore, the relative decline in foreign bills in the discounters' sample during the crisis month (very relative, as it nonetheless remained a hefty $65 \%$ ) does reflect the scramble for cash and the use of domestic bills that did not normally reach the central bank. This is reflected by the rise in the number of acceptors with a greater domestic orientation. Using our "top discounters" sample, we found 369 identifiable acceptors in May 1865, but 1055 in May 1866: this increase is much more substantial than the increase in the number of discounters (see Table 3a). ${ }^{51}$ Figure 8 looks at the domestic/foreign decomposition of the material turned in by "bill brokers", "commercial banks" and "merchant banks and trading houses" in 1865 and 1866. As can be seen, the increase in domestic material occurred across the board. Therefore, the increase in domestic paper had not so much to do with changes in the identity of discounters, but with the fact that customers brought to the Bank proportionately more of the domestic instruments.

\footnotetext{
${ }^{50}$ Computed from stamp duty statistics from Hughes (1960, p. 299)

${ }^{51}$ Note that this latter number is vastly superior to that for discounters with access to the Bank of England.
} 


\section{b) Key Acceptors}

Tables $5 \mathrm{a}$ and $\mathrm{b}$ document, for each period, the ranking and the market share of the biggest acceptors in the "top acceptors" sample. As can be seen, both ranks and market shares are rather stable. Since this corresponds more closely to the biggest acceptors in either period of both, the suggestion is that, unlike discounters, the ranking of acceptors (i.e. the composition of what was brought, in terms of accepting houses) did not change much notwithstanding the big increase in their total number. One major finding that emerges is that merchant banks hardly represent the only, let alone the main, source of acceptances. ${ }^{52}$ Contrary to what has been often emphasized, several commercial banks were a prominent source of acceptances in this early period. This seems to be in blatant conflict with accounts that have emphasized the undisputed role of merchant banks in this market. Of course, it could be that there is a major selection bias in the Bank of England material. It could also be that the rise of the supremacy of merchant banks was a later phenomenon although scholars usually argue exactly the opposite. ${ }^{53}$ Another interpretation is that the market for acceptances was much more diverse and scattered than has been recognized so far and that the Bank of England, rather than delegating to a few prestigious house the responsibility to screen the bills, preferred to diversify its exposure. We will come back to this issue in Section V.

Next, we ask whether and how things changed with the crisis. We saw that rankings remained stable at the top, but this could go along with many entries at the bottom. ${ }^{54}$ Figure 9 documents the market share of the top ten and top three acceptors in 1865 and 1866, and compares it to rankings for discounters. We see that while top discounters controlled a greater share of totals during the crisis, the share controlled by top acceptors remained stable, emphasizing that the great change was with the amounts brought rather than with the nature of the paper presented.

Another interesting thing that can be explored with the help of our data is the way the paper brought to the Bank had been structured. This we do by looking at the material drawn upon a number of leading acceptors. The reason for focusing on leading acceptors is tied to the fact that these will have endorsed substantial values, making inferences more meaningful. There are several ways in which acceptances per acceptor can be organized. We look here at geographical make in order to assess whether acceptors were diversified geographically. ${ }^{55}$ Results, for 10 leading acceptors are shown in Figure 10a and b. ${ }^{56}$ Different acceptors had different geographic bias. One sees for instance the importance of drafts from the United States and Caribbean in Rothschilds' acceptances, or the importance of the US for Barings, or that of the Mediterranean for Fruhling \& Goschen. Therefore, the

\footnotetext{
52 . This result is fully robust to considering the "top discounters" sample instead.

53 . See above and also Withers (1910, p. 56)

54 . The numbers we find for the number of acceptors in the two portfolios of "top discounters" for each period suggest a drastic increase in the number of acceptors.

55. Most accounts suggest they were not (Chapman 1984).

56. The selection was mostly heuristic and we do not seek to make any general inference. There are four commercial banks and six merchant banks. Bill brokers do not appear as they usually did not accept bills.
} 
conventional view that bankers on whom drafts were drawn operated in niches, where they had information advantages, is fully supported by the data.

A big finding from Figure 10 is that foreign bills were by no mean the exclusive hunting ground of merchant banks. The vast majority of paper on the London Joint-Stock Bank or on the Colonial Bank, for instance, was drawn from abroad. Paper on Barings, on the other hand, included a non-trivial amount of domestic drafts. Of course, banks with clear domestic orientation, such as Barclay \& Co., show a much greater share of domestic drafts - as one would expect. In fact the real split is with the political arrangements prevailing in the foreign zone(s) under consideration: commercial banks shown mostly drafts from the British Empire (India, Caribbean, Australia, Hong Kong, and Singapore), while merchant banks were drawn by correspondents in non-Empire locations (the US, Latin America, the Continent). ${ }^{57}$

\section{c) Geography of Acceptances}

To conclude, we now take a look at the aggregate geography of acceptances. Focusing on the "top discounters" sample, we document the spatial breakdown for bills drawn abroad, and compare it with data on the structure of British trade at about the same date. The assumption, implicit in this exercise, is that there is a sort of "gravity theory" for London bills, which would have brought the imprint of British trade. In other words, as trade finance provided the infrastructure for the development of the money market, regions heavily related to Britain as far as trade is concerned ought to have also drawn more bills on London bankers, and this should be reflected in the composition of the portfolio we study. This is consistent with the notion that the Bank of England did not set its face against the development of the London money market along lines heavily influenced by international trade.

To construct the relevant data, we extracted information on the drawing place for all bills covered by the "top discounters" sample. This was performed for both May 1865 and May 1866. Then we extracted from the Statistical Abstract for the principal and other foreign countries et le Statistical Abstract for the several colonial and other possessions of the United Kingdom material to organize a cross section analysis of the geographical composition of British trade for the year 1865. Both databases were then aggregated in the following way. We identified five main geographic areas that corresponded to broad regions with trade relevance for Britain: British Empire, Northern European markets (Holland, Scandinavia, Northern Germany, the Baltic, and Russia), Latin America and the Caribbean, the United States of America, and finally "Other" which covers the rest of Europe, nonEmpire Asia and Africa, and the Middle East.

The correspondence between trade and finance is shown in Figure 11. While there is no formal criterion to judge the "fit" of the two distributions, the eye impression is indeed one that is consistent with the assumption that trade patterns were closely associated with financial patterns. This is a striking result: our exploration of the portfolio of acceptances bought by the Bank of England yields a

\footnotetext{
${ }^{57}$ This is consistent with Chapman's (1984, pp. 111-5) claim that the finance of Eurasian trade was left open to newly-founded commercial banks by the collapse of agency houses after the 1847 crisis.
} 
map which is not dissimilar to that implied by the statistics of the Board of Trade. We conclude that this vindicates the view of an association between British trade supremacy and the rise of sterling as an international currency supported by the National Monetary Commission. We also add a twist to the story: It is probably no coincidence that the dramatic increase in international trade of the mid- $19^{\text {th }}$ century immediately preceded the rise of modern central banking. During the 1850s and 1860s, both old (merchant banks) and new institutions (joint stock banks) took advantage of the expansion of global trade and of London financial know-how to boost, with the help of a booming "shadow banking system", the size and liquidity of the sterling money market. To perfect this market the help of the Bank of England was needed, and given the importance finance had for British political supremacy, it is perhaps not surprising that the Bank of England, despite its vituperation against the bill brokers, found itself doing what was needed when it was needed.

\section{Section V. Lending of Last Resort and Supervision}

The pending question is that of determining whether the Bank of England's policy created moral hazard. As indicated, it has often been argued in the literature that the salient ingredient of $19^{\text {th }}$-century Bank of England lending (and of its transformation into a modern central bank) reached its more perfect stage when it managed (in the age of Bagehot) to ignore the identity of borrowers as long as good collateral would be brought in for discount (Goodhart 1988, Capie 2002). To some extent, this view is vindicated by our finding that the 1866 crisis changed the identity of those who came to secure liquidity more dramatically than it changed observable characteristics of the paper that was turned in. On the other hand, our evidence brings some substantial qualification to this conventional picture.

Had Bank of England lending been really anonymous, one would expect its counters to have been fully open to the public: in principle, anybody bringing in good collateral should have been entitled to borrow. Yet this was not the case. People eligible to borrow from the Bank were part of an exclusive club whose membership was subject to a number of conditions; what is more, as Bignon, Flandreau and Ugolini (2011) find, "membership" shrank dramatically throughout the $19^{\text {th }}$ century. This did reflect in part consolidation in the banking industry, but not only. In spite of the expansion of London as an international financial centre, the Bank of England was restricting direct access to its discount window.

Another issue is that of determining what 'good collateral' actually was. In the case of advances, the definition of good collateral might have been rather plain, consisting of those exchange-traded securities considered as eligible by the Bank, although "haircuts" were probably applied and we suspect they were based on the "character" of the customer, and not only on the collateral. ${ }^{58}$ Discounts

\footnotetext{
${ }^{58}$ Unfortunately, we lack information concerning the size and determinants of the haircuts. Since advances were closely monitored by the Bank on a per-customer basis (as shown in Table 2), we cannot exclude that haircuts
} 
revealed a similar pattern. While "normally" generated in the course of actual transactions and for the finance of "physical" commodity shipping, the bill of exchange was, from a legal point of view, more similar to a promissory note with multiple guarantees rather than to an physical asset-backed security. In case of default of the acceptor, the holder of the bill (e.g. the Bank of England) had the right to ask for its payment from its last endorser (viz. the person from whom the bill had been discounted/purchased), who in turn could get even with previous endorsers; in no case, however, the holder had the right to seize directly the collateral that might have been mentioned on the bill (Seyd 1868, pp. 81-3). The commodities explicitly mentioned on the bill did not represent a material lien and may have acted as a "psychological" guarantee that the people involved in the transaction (either the acceptor or the drawer, who was legally equivalent to the first endorser) were not engaged in phony operations and would therefore be able to meet their engagements at maturity; in case of default of all the people involved, the discounter had the right to seize a proportional share of the debtors' assets, not the commodities concerned by the given transaction. This means that the "value" of a bill of exchange was the names written of it (acceptors and discounters) -- hardly an anonymous feature!

Differently said, the collateral that backed a bill discounted by the Bank of England was not a real commodity or transaction but the character of the participants to the origination of the bill and the belief that the Bank had leverage over this character (perhaps because access to the discount window created value). Withers (1920) summarized this process, through which the so-called finance bill had come into being ${ }^{59}$, by saying that the acceptor had "grown from a merchant into an accepting house" This is according to him through that process that finance bills (that did not provide any motive for the credit operation) had become the staple instrument of the London money market. As one can see from London money market bulletins published by The Economist, prime finance bills (i.e. endorsed by

were charged according to the borrower's own situation and rating. As a result, even purely collateralized lending by the Bank was probably not anonymous.

59 . "It is this quality, inherent in a genuine bill, which gave rise to the saying that banking is the easiest possible business to conduct, when once the banker has grasped the difference between a bill of exchange and a mortgage. We have seen that the genuine bill of exchange is easily negotiable before maturity, and on maturity is cash by the sale of the goods on which it is based. [...] But, as a matter of practical fact, a very large number of the bills drawn are not of this genuine character, and the use of this admirable and efficient instrument of credit has been so extended, that the distinction between it and a mortgage on real property is nowadays sometimes in favour of the latter, which has at any rate something behind it. [...] More often the bill takes a form like this: 'At ninety days after sight of this First of Exchange (Second Unpaid) pay to the order of Messrs. Jones Two Thousand Pounds Sterling, Value received, and charge the same to a/c as advised'. Experts in credit may be able to hazard a shrewd guess from the appearance of a bill, as to what is behind it. But the phrase 'Value received' covers a multitude of mystery, and the difference between a genuine produce bill and a piece of finance paper is often difficult to detect" (Withers 1920, pp. 46-53).

60 . "When John Smith [a fictive acceptor] is described as having grown from a merchant into an accepting house, he is supposed to have passed through a process which has been fairly common experience. Like many other merchant houses, he has given up the actual handling and selling of merchandise, though retaining the title of merchant, which is highly honoured in the City, and is confining his attention to the profits which he can more easily earn, if his name be good enough, by placing his acceptance at the disposal of borrowers who want to draw on him. The arrangement that he has made with Watt's [a fictive drawer] banker, and with many other dealers in bills of exchange in other parts of the world, enables them to draw on one another at any time, whether there be produce passing or no, and brings into being the instrument known as a finance bill. By this operation he and they create credit instruments which can be discounted and turned into cash, on the security of their names which are on the bills" (Withers 1920, pp. 48-9, our italics). 
first-class financial intermediaries) were constantly discounted in the open market at a lower interest rate than trade bills (endorsed by firms specialized in trade rather than in banking).

The implication of all this is that lending could not be anonymous even in case the Bank of England had really wished it to be so. Even if its discount window had been "made of frosted glass", by looking at the paper pushed through the chink, the Bank would have immediately known who was on the other side of the window. When it examined the paper, it immediately saw names (information provided by the bill itself) and it is on the basis of these names that it made its decision. This, we argue is the reason why the Bank thought it wise to put in place the monitoring system described in section I, which allowed it to constantly monitor its own exposure towards individual acceptors and discounters, but also quite certainly to track with accuracy whether certain market participants were overextending credit. It is likely that the Bank of England could act upon this information.

This conclusion is of utmost importance to understand how and why the new policies adopted by the Bank of England in the 1860s did not succumb to moral hazard. The system that emerges from the analysis above can be described as a cascade of embedded monitoring and screening operations. The acceptors were in charge of screening the drawers, whom the Bank of England never saw, since there were often foreign residents. The large number of top accepting houses, we found, rarely or never discounted at the Bank although the Bank held big amounts of bills accepted by them. This suggests that they acted as competitive delegated certifiers (akin to competitive rating agencies) working for the market and committed to honor their pledges and make ends meet. Obviously, their credit would have been badly damaged if the Bank of England had started refusing their paper, and this would have driven them out of the profitable acceptance market. ${ }^{61}$

In effect, the discount window was the place where the Bank supervisory role was really enforced through tight monitoring of discounters. Monitoring of discounters took the form of guarantees taken on discounters' assets, reputation (discounters had to be "introduced"), word of mouth, or the request to make a deposits. The guarantees taken by the Bank protected it against losses, of which, in practice, discounters bore all risks. In case acceptors would not pay, discounters would be immediately asked to refund the Bank - and if unable to do so, they would be expelled from the club. This implies that the discounters were also effectively charged with the responsibility to screen acceptors, just as acceptors were expected to screen drawers. It also implies that the enforcement of this system worked because discounters feared of being deprived of membership to the club. Exclusion from the discount window in effect forced valuable information to be revealed and limited moral hazard. To put it bluntly, the Bank of England did limit moral hazard by not lending "anonymously". This was permitted by the combination of an accurate, individualized screening procedure and individualized penalties that rested on the Bank's crisis lending monopoly and on its credible exclusion threats.

\footnotetext{
${ }^{61}$ There were a number of practical issues that facilitated control of discounters too. As time passed the practice of discounting parcels of bills became widespread. Parcels were presented by one discounter but might be made of bills accepted by myriads of different people: in such cases, verification costs became prohibitive and threatened to clog the workings of the Bank.
} 


\section{Conclusions}

This paper has brought fresh light on the relation between central banking, crisis lending, the shadow banking system, and the making of sterling as an international currency, providing emphasis on the relation between the Bank of England and the international money market. We used so-far unexplored Bank of England's ledgers to provide a picture of liquidity provision during both stress periods (May 1866, when the Overend-Gurney panic reached its apex) and "normal times" (May 1865, or one year earlier). Important findings include:

the considerable diversity of discounters, and the even greater diversity of acceptors;

the spectacular increase in amounts discounted by some houses in crisis period, and the concurrent increase in the diversity of the material that was discounted;

the emergence of new borrowers when crisis hit - and among them, the considerable importance of bill brokers: while brokers were not coming to the Bank in normal times, they drew about one third of total cash during the crisis;

the large predominance of foreign bills;

the very diverse nature of the market for bills: many houses, both merchant banks and commercial banks (all with geographical niches) were being drawn upon by a vast array of correspondents;

the lack of a predominant source of acceptance at this date, with leading acceptance firms never controlling more than a tiny fraction of the totals brought to the Bank;

and finally, the overlap between the geographical reach of British trade and the geographical composition of acceptances.

While several of these findings have been anticipated in earlier literature, some actually run counter to modern wisdom (or go on side tracks). For instance, we provide additional evidence that the assets forming the London money market were very international at an early time. From a political economy point of view, it implies an extremely tight relation between the London money market and international trade finance.

Another important feature that emerges from the evidence here is the enormous importance of specialized operators of the London money market, namely the bill brokers. While British writers commissioned by the National Monetary Commission saw them (as already stated) as "chiefly ancillary to banks", we found that their refinancing was a central facet of lending of last resort. Why was it so? Perhaps, given the scattered nature of the products traded in the London money market, there was a serious need for experts to be able to sort bills and construct portfolios, and thus screen, secure, and eventually make ends meet. These specialized dealers did not compete against commercial banks, and as a result they were wholly interested in the success of the market they operated. They provided the Bank of England with a convenient instrument to support the market at arm's length. Conversely, to keep ensuring the liquidity of bills, given the risk of mismatch, the bill brokers 
obviously needed the Bank of England just as badly as the Bank needed their knowledge to screen risks.

Thus in summary, while international trade provided one necessary condition for a successful market for acceptances to emerge (the National Monetary Commission's insight), other microstructural features were needed, and they included the bill brokers and the Bank of England's lending of last resort operations - together with the monopoly on crisis lending and the enforcement power over money market participants these operations implied. That this was not emphasized too strongly by British experts when asked by American policy makers should not surprise us exceedingly. There, after all, laid the secret of making fire. 


\section{Archival Sources}

Bank of England Archive (London), Cashiers' Department:

C22/27-34 (Discounters' Ledgers)

C23/3 (Drawing Office Discounters' Ledgers)

C24/1 (Bankers' Ledgers)

C25/3 (Brokers' Ledgers)

C28/15 and 25-26 (Daily Discounts)

C30/3 (Discount Office Accounts: Analyses and Summaries)

\section{References}

Aldrich, Nelson W. (ed.) (1910), Interviews on the Banking and Currency Systems of England, Scotland, France, Germany, Switzerland, and Italy, Washington: Government Printing Office, $61^{\text {st }}$ Congress, $2^{\text {nd }}$ Session, Senate Doc. 405.

Bagehot, Walter (1873), Lombard Street: A Description of the Money Market, London: King.

Bankers' Almanac (1866) [Banking almanac : containing a complete banking directory of the United Kingdom and the British colonies, the principal banks of the world, and a bankers' guide to the principal insurance offices.]

Bignon, Vincent, Marc Flandreau, and Stefano Ugolini (2011), "Bagehot for Beginners: The Making of Lending of Last Resort Operations in the Mid-19 ${ }^{\text {th }}$ Century", forthcoming, Economic History Review.

Broz, J. Lawrence (1997), International Origins of the Federal Reserve System, Ithaca: Cornell University Press.

Capie, Forrest (2002), "The Emergence of the Bank of England as a Mature Central Bank", in Donald Winch and Patrick K. O'Brien (eds.), The Political Economy of British Historical Experience, 1688-1914, Oxford: Oxford University Press, pp. 295-315.

Chapman, Stanley (1984), The Rise of Merchant Banking, London: Routledge.

Clapham, John H. (1944), The Bank of England: A History, Cambridge: Cambridge University Press.

Clare, George (1891), A Money Market Primer, and Key to the Exchanges, London: Effingham Wilson.

Eichengreen, Barry J. and Marc Flandreau, 2010, "The Federal Reserve, the Bank of England, and the Rise of the Dollar as an International Currency, 1914-1939”, BIS working paper. 
Fetter, Frank W. (1965), Development of British Monetary Orthodoxy, 1797-1875, Cambridge (Mass.): Harvard University Press.

Flandreau, Marc (2004), The Glitter of Gold: France, Bimetallism and the Emergence of the International Gold Standard, 1848-1873, Oxford: Oxford University Press.

Flandreau, Marc, and François Gallice (2005), "Paris, London and the International Money Market: Lessons from Paribas 1885-1913." In Paris and London as International Financial Centers, edited by Youssef Cassis and Eric Bussière, 78-106. Oxford: Oxford University Press.

Flandreau, Marc and Clemens Jobst, (2005), "The Ties that Divide: A Network Analysis or the International Monetary System, 1890-1910" The Journal of Economic History, December, Vol. 65. ํㅜ 4, p. 977-1007.

Goodhart, Charles A. E. (1972), The Business of Banking, 1891-1914, London: Weidenfeld \& Nicolon.

Goodhart, Charles A. E. (1988), The Evolution of Central Banks, Cambridge (Mass.): MIT Press.

Jacobs, Lawrence M. (1910), Bank Acceptances, Washington: Government Printing Office, $61^{\text {st }}$ Congress, $2^{\text {nd }}$ Session, Senate Doc. 569.

Gorton, Gary, 2010, "Questions and Answers about the Financial Crisis, Paper Prepared for the U.S. Financial Crisis Inquiry Commission" Mimeo, Yale University.

Hidy, Ralph W. (1949), The House of Baring in American Trade and Finance: English Merchant Bankers at Work, 1763-1861, Cambridge (Mass.): Harvard University Press.

Hughes, Jonathan R. T. (1960), Fluctuations in Trade, Industry and Finance: A Study of British Economic Development, 1850-1860, Oxford: Clarendon Press.

Jenks, Leland H. (1927), The Migration of British Capital to 1875, New York: Knopf.

King, Wilfred, T. C., (1935), "The Extent of the London Discount Market in the Middle of the Nineteenth Century”, Economica, New Series, Vol. 2, No. 7 (Aug., 1935), pp. 321-326.

King, Wilfred T. C. (1936), History of the London Discount Market, London: Routledge.

Nishimura, Shizuya (1971), The Decline of Inland Bills of Exchange in the London Money Market, 1855-1913, Cambridge: Cambridge University Press.

Okazaki, Tetsuji (2007), "Micro-Aspects of Monetary Policy: Lender of Last Resort and Selection of Banks in Prewar Japan”, Explorations in Economic History 44:4, pp. 657-679.

Palgrave, R. H. Inglis (1903), The Bank Rate and the Money Market in England, France, Germany, Holland, and Belgium, 1844-1900, London: Murray.

Perkins, Edwin J. (1975), Financing Anglo-American Trade: The House of Brown, 1800-1880, Cambridge (Mass.): Harvard University Press.

Philippovich, Eugen von (1910), History of the Bank of England and its Financial Services to the State, Washington: Government Printing Office, $61^{\text {st }}$ Congress, $2^{\text {nd }}$ Session, Senate Doc. 591.

Rozenraad, Cornelius (1900), "The International Money Market”, Journal of the Royal Statistical Society 63:1, pp. 1-40. 
Sayers, Richard S. (1936), Bank of England Operations, 1890-1914, London: King.

Sayers, Richard S. (1968), Gilletts in the London Money Market, 1867-1967, Oxford: Clarendon Press.

Sayers, Richard S. (1976), The Bank of England, 1891-1944, Cambridge: Cambridge University Press.

Seyd, Ernest (1868), Bullion and Foreign Exchanges, Theoretically and Practically Considered, London: Effingham Wilson.

Statistical Abstract for the principal and other foreign countries et le Statistical Abstract for the several colonial and other possessions of the United Kingdom, London: HMSO, 1866.

Tamaki, Norio (1974), “The Merchant Bankers in the Early 1830s”, Keio Business Review 13, pp. 59-70.

The Economist (1866).

Tullio, Giuseppe, and Jürgen Wolters (2003a), “The Objectives of British Monetary Policy during the Classical Gold Standard, 1876-1913: An Econometric Analysis of Domestic and Foreign Determinants of Bank Rate", Discussion Paper n. 13, Freie Universität Berlin, Fachbereich Wirtschaftswissenschaften.

Tullio, Giuseppe, and Jürgen Wolters (2003b), “The Objectives of French Monetary Policy during the Classical Gold Standard, 1876-1913; An Econometric Analysis of the Determinants of the Banque de France's Official Discount Rate", Discussion Paper n. 12, Freie Universität Berlin, Fachbereich Wirtschaftswissenschaften.

Tullio, Giuseppe, and Jürgen Wolters (2003c), “The Objectives of German Monetary Policy during the Classical Gold Standard, 1876-1913: An Econometric Analysis of the Determinants of the Reichsbank's Official Discount Rate”, Disc. Paper n. 14, Freie Universität Berlin, Fachbereich Wirtschaftswissenschaften.

Tullio, Giuseppe, and Jürgen Wolters (2007), "Monetary Policy in Austria-Hungary, 1876-1913: An Econometric Analysis of the Determinants of the Central Bank's Discount Rate and the Liquidity Ratio”, Open Economies Review 18:5, pp. 521-537.

Ugolini, Stefano (2011), “An 'Atypical' Case? The First Emergence of Brussels as an International Financial Centre, 1830-1860", in Youssef Cassis and Laure Quennouëlle-Corre (eds.), Institutions, Markets and Capital Flows from the 1880s to the Present: Why Are Financial Centres Attractive?, Oxford: Oxford University Press, forthcoming.

Warburg, Paul M. (1910), The Discount System in Europe, Washington: Government Printing Office, $61^{\text {st }}$ Congress, $2^{\text {nd }}$ Session, Senate Doc. 402.

Withers, Hartley (1910), “The English Banking System”, in id., R. H. Inglis Palgrave, Ernest Sykes, and Robert M. Holland (1910), The English Banking System, Washington: Government Printing Office, $61^{\text {st }}$ Congress, $2^{\text {nd }}$ Session, Senate Doc. 492, pp. 3-148.

Withers, Hartley (1920), The Meaning of Money, New York: Dutton. 
Table 1. An excerpt from the "Daily Discounts" ledgers (May $3^{\text {rd }}, 1866$ ).

\begin{tabular}{|c|c|c|c|c|c|c|c|c|c|c|c|}
\hline \multicolumn{12}{|c|}{ Thursday, 3rd May, 1866} \\
\hline \multicolumn{3}{|c|}{$\begin{array}{l}\text { Amount of Bills Discounted going off } \\
\text { Amount of Advances going off }\end{array}$} & \multicolumn{3}{|c|}{$\begin{array}{r}£ 92.000,00 \\
£ \quad 3.000,00 \\
\end{array}$} & \multicolumn{5}{|c|}{$\begin{array}{r}\text { Amount Discounted } \\
\text { Amount Advanced }\end{array}$} & $\begin{array}{l}£ 145.708,00 \\
£ \quad 17.600,00 \\
\end{array}$ \\
\hline \multirow[t]{2}{*}{$\begin{array}{c}N^{\circ} \text { of Bills } \\
\text { Brought in } \\
\text { for Discount }\end{array}$} & \multirow[t]{2}{*}{$\begin{array}{c}\text { Rate } \\
\text { Per } \\
\text { Cent }\end{array}$} & \multirow[t]{2}{*}{$\begin{array}{c}\text { For whom Discounted, or } \\
\text { To whom Advanced }\end{array}$} & \multicolumn{3}{|c|}{$\begin{array}{l}\text { Amount of Bills } \\
\text { Brought in for } \\
\text { Discount }\end{array}$} & \multirow[t]{2}{*}{$\begin{array}{c}N^{\circ} \text { of Bills } \\
\text { Rejected }\end{array}$} & \multicolumn{3}{|c|}{$\begin{array}{l}\text { Amount } \\
\text { Rejected }\end{array}$} & \multirow{2}{*}{$\begin{array}{c}\text { Amount } \\
\text { Advanced } \\
\qquad \\
\qquad\end{array}$} & \multirow[t]{2}{*}{ Remarks } \\
\hline & & & $f$ & $s$ & $d$ & & $£$ & $s$ & $d$ & & \\
\hline 10 & 7 & Hooper R \& Sons & 3.258 & 12 & 11 & & & & & & \\
\hline 2 & 7 & Jenkinson W & 221 & 12 & & & & & & & \\
\hline 6 & 7 & Hart J \& Co & 6.865 & & & 1 & 1.200 & & & & Sighting Altered \\
\hline 13 & 7,5 & Lloyd \& Attree & 300 & 19 & 4 & & & & & & \\
\hline 5 & 7 & Nelson T \& Son & 562 & & & & & & & & \\
\hline 1 & 7 & Lovering \& Minton & 500 & & & 1 & 500 & & & & Beyond 95 Days \\
\hline 6 & 7 & Rattray W \& Co & 1.350 & & & & & & & & \\
\hline 11 & 7 & Sieveking Droops \& Co & 5.643 & 13 & 2 & & & & & & \\
\hline 19 & 7 & Morgan Bros & 5.698 & 6 & 7 & 8 & 3.501 & 10 & 4 & & \\
\hline 1 & 7 & Bailey Pegg \& Co & 1.000 & & & & & & & & \\
\hline 6 & 7,5 & Stephenson Clarke & 2.537 & 12 & 2 & 2 & 745 & 7 & 9 & & \\
\hline 5 & 7 & Rutherford Drury \& Co & 864 & 7 & 6 & 1 & 131 & 8 & 3 & & Beyond 95 Days \\
\hline 6 & 7 & Tamvass Mierulachi \& Co & 4.329 & 18 & 10 & & & & & & \\
\hline 3 & 7 & Naylor Benzon \& Co & 2.973 & 12 & 1 & & & & & & \\
\hline 17 & 7 & Hooper R \& Sons & 1.623 & 7 & 9 & & & & & & \\
\hline 23 & 7 & Smith Fleming \& Co & 44.007 & 6 & 11 & & & & & & \\
\hline 40 & 7 & The Colonial Co Ltd & 31.962 & 13 & 5 & & & & & & \\
\hline 15 & 7 & Bell A \& Co & 6.972 & 2 & 9 & & & & & & \\
\hline 3 & 7 & Gaury J \& Co & 4.832 & 3 & & & & & & & \\
\hline 2 & 7 & Hart J \& Co & 951 & 12 & 3 & & & & & & \\
\hline 8 & 7 & Gibbs A \& Sons & 25.332 & 4 & 10 & & & & & & \\
\hline & 7 & Byass \& Son & & & & & & & & 8.000 & \\
\hline & 7 & Pawson JF \& Co & & & & & & & & 9.600 & \\
\hline 202 & & & 151.787 & 5 & 11 & 13 & 6.078 & 6 & 4 & 17.600 & \\
\hline
\end{tabular}

Source: Bank of England Archive, Daily Discounts, C28/26. 
Table 2. Excerpt from Smith, Fleming \& Co.'s entry in Bank of England's “Discounters" ledgers.

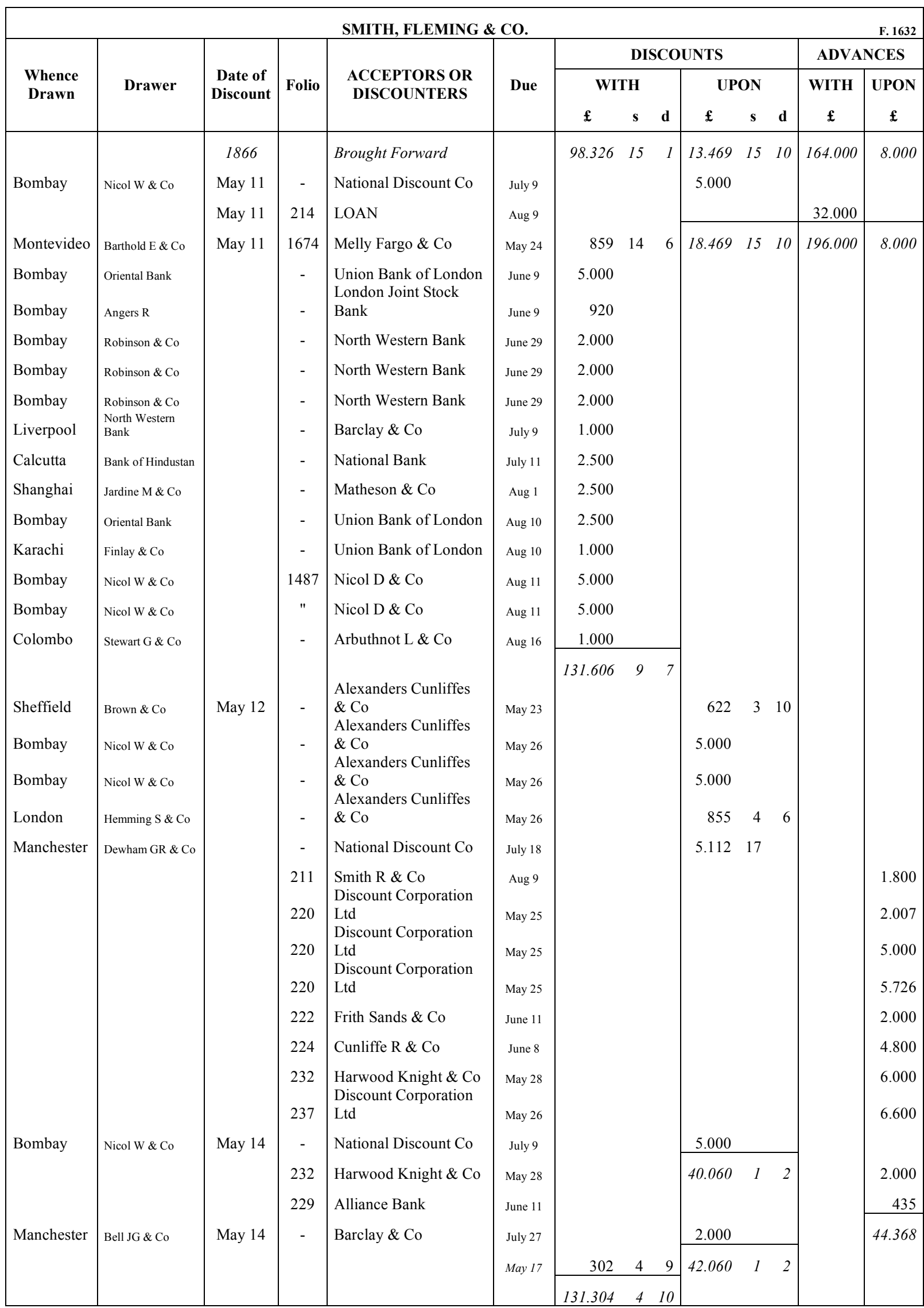

Source: Authors, fromBank of England Archive, Discounters' Ledgers, C22/34. 
Tables 3a and b. Descriptive Statistics for the Population of Borrowers.

\begin{tabular}{|l|r|l|r|}
\hline \multicolumn{4}{|c|}{ Discounts } \\
\hline \multicolumn{2}{|c|}{ May 1865 } & & \multicolumn{2}{c|}{ May 1866 } \\
\hline Number & 269 & Number & 372 \\
\hline \% of Bank's Customers & $61 \%$ & \% of Bank's Customers & $74 \%$ \\
\hline Min & 30.00 & Min & 43.81 \\
\hline Max & $100,974.62$ & Max & $692,520.76$ \\
\hline Mean & 7.999 .22 & Mean & $27,584.59$ \\
\hline Median & $3,690.00$ & Median & $5,820.18$ \\
\hline Total & $2,151,791.03$ & Total & $10,261,467.88$ \\
\hline
\end{tabular}

\begin{tabular}{|l|r|l|r|}
\hline \multicolumn{5}{|c|}{ Advances } \\
\hline \multicolumn{1}{|c|}{ May 1865 } & & \multicolumn{2}{c|}{ May 1866 } \\
\hline Number & 25 & Number & 69 \\
\hline \% of Bank's Customers & $6 \%$ & \% of Bank's Customers & $14 \%$ \\
\hline Min & $1,200.00$ & Min & 800.00 \\
\hline Max & $138,000.00$ & Max & $750,000.00$ \\
\hline Mean & $20,084.00$ & Mean & $74,611.59$ \\
\hline Median & $10,400.00$ & Median & $20,000.00$ \\
\hline Total & $502,100.00$ & Total & $5,148,200.00$ \\
\hline
\end{tabular}

Source: Authors, from database. 
Table 4. Share of Foreign Bills in Bank of England's Discounts, selected dates.

\begin{tabular}{|c|l|r|l|}
\hline Date & \multicolumn{1}{|c|}{ Method } & $\begin{array}{c}\text { Percent. } \\
\text { Foreign } \\
\text { Bills }\end{array}$ & Source \\
\hline 1800 & $\begin{array}{l}\text { "Amounts Discounted to Agents with Specialized Activities" } \\
\text { (see Clapham 1944, I, pp. 205-6) }\end{array}$ & $32.5 \%$ & $\mathrm{M} 6 / 1$ \\
\hline & $\begin{array}{l}\text { "Amounts Discounted to Agents with Specialized Activities" } \\
\text { (see Clapham 1944, I, pp. 205-6) }\end{array}$ & $35.5 \%$ & $\mathrm{M} 6 / 1$ \\
\hline 1810 & Bank of England Ledgers & $35.5 \%$ & $\mathrm{C} 28 / 14$ \\
\hline 1854 & Bank of England Ledgers & $43.8 \%$ & $\mathrm{C} 28 / 15$ \\
\hline 1855 & Bank of England Ledgers & $45.6 \%$ & $\mathrm{C} 28 / 16$ \\
\hline 1856 & Bank of England Ledgers & $51.5 \%$ & $\mathrm{C} 28 / 19$ \\
\hline 1865 & Estimated from sample of "top discounters" & $85.0 \%$ & authors \\
\hline 1866 & Estimated from sample of "top discounters" & $63.0 \%$ & authors \\
\hline
\end{tabular}

Source: Authors, from Bank of England Archive 
Tables $5 \mathrm{a}$ and $\mathrm{b}$. Rankings of top 25 acceptors from the "top acceptors" sample.

\begin{tabular}{|r|l|r|r|}
\hline \multicolumn{3}{|c|}{ May 1865 } \\
\hline 1 & London Joint Stock Bank & $166^{\prime} 862.66$ & $7.75 \%$ \\
\hline 2 & Union Bank of London & $84^{\prime} 419.34$ & $3.92 \%$ \\
\hline 3 & London \& County Bank & $69^{\prime} 317.37$ & $3.22 \%$ \\
\hline 4 & City of Glasgow Bank & $52^{\prime} 555.49$ & $2.44 \%$ \\
\hline 5 & Imperial Ottoman Bank & $42^{\prime} 580.81$ & $1.98 \%$ \\
\hline 6 & Frühling \& Goschen & $42^{\prime} 560.03$ & $1.98 \%$ \\
\hline 7 & The City Bank & $39^{\prime} 170.67$ & $1.82 \%$ \\
\hline 8 & Drake Kleinwort \& Cohen & $29^{\prime} 261.21$ & $1.36 \%$ \\
\hline 9 & Bank of London & $26^{\prime} 359.61$ & $1.23 \%$ \\
\hline 10 & Agra \& Masterman's Bank & $24^{\prime} 504.00$ & $1.14 \%$ \\
\hline 11 & Baring Brothers \& Co & $21^{\prime} 635.55$ & $1.01 \%$ \\
\hline 12 & Finlay Campbell \& Co & $19^{\prime} 216.32$ & $0.89 \%$ \\
\hline 13 & F Huth \& Co & $19^{\prime} 029.89$ & $0.88 \%$ \\
\hline 14 & The National Bank & $15^{\prime} 793.46$ & $0.73 \%$ \\
\hline 15 & Finlay Hodgson \& Co & $14^{\prime} 456.01$ & $0.67 \%$ \\
\hline 16 & NM Rothschild \& Sons & $12^{\prime} 853.00$ & $0.60 \%$ \\
\hline 17 & Union Bank of Australia & $12^{\prime} 498.68$ & $0.58 \%$ \\
\hline 18 & Dadalhai Naoroji \& Co & $12^{\prime} 000.00$ & $0.56 \%$ \\
\hline 19 & Glyn Mills Currie \& Co & $11^{\prime} 956.26$ & $0.56 \%$ \\
\hline 20 & Merchant Banking Co of London & $11^{\prime} 264.87$ & $0.52 \%$ \\
\hline 21 & Oriental Bank Corporation & $11^{\prime} 139.60$ & $0.52 \%$ \\
\hline 22 & Moses Brothers & $10^{\prime} 200.00$ & $0.47 \%$ \\
\hline 23 & Colonial Bank & $10^{\prime} 179.34$ & $0.47 \%$ \\
\hline 24 & Alliance Bank & $9^{\prime} 101.34$ & $0.42 \%$ \\
\hline 25 & JH Schroder \& Co & $777^{\prime} 337.08$ & $0.39 \%$ \\
\hline & TOTAL & $36.13 \%$ \\
\hline
\end{tabular}

\begin{tabular}{|r|l|r|r|}
\hline \multicolumn{3}{|c|}{ May 1866 } \\
\hline 1 & London Joint Stock Bank & $637^{\prime} 028.01$ & $6.21 \%$ \\
\hline 2 & Union Bank of London & $474^{\prime} 520.92$ & $4.62 \%$ \\
\hline 3 & The National Bank & $321^{\prime} 824.83$ & $3.14 \%$ \\
\hline 4 & Frühling \& Goschen & $279^{\prime} 321.03$ & $2.72 \%$ \\
\hline 5 & Agra \& Masterman's Bank & $191^{\prime} 511.83$ & $1.87 \%$ \\
\hline 6 & The City Bank & $188^{\prime} 088.95$ & $1.83 \%$ \\
\hline 7 & North Western Bank & $175^{\prime} 129.64$ & $1.71 \%$ \\
\hline 8 & London \& County Bank & $150^{\prime} 793.66$ & $1.47 \%$ \\
\hline 9 & Baring Brothers \& Co & $147^{\prime} 425.16$ & $1.44 \%$ \\
\hline 10 & Royal Bank of Liverpool & $146^{\prime} 905.89$ & $1.43 \%$ \\
\hline 11 & Drake Kleinwort \& Cohen & $144^{\prime} 033.20$ & $1.40 \%$ \\
\hline 12 & F Huth \& Co & $125^{\prime} 467.88$ & $1.22 \%$ \\
\hline 13 & Finlay Hodgson \& Co & $123^{\prime} 896.58$ & $1.21 \%$ \\
\hline 14 & City of Glasgow Bank & $96^{\prime} 051.60$ & $0.94 \%$ \\
\hline 15 & JS Morgan \& Co & $95^{\prime} 764.03$ & $0.93 \%$ \\
\hline 16 & Bank of Liverpool & $85^{\prime} 577.62$ & $0.83 \%$ \\
\hline 17 & Ebbw-Vale Company Limited & $80^{\prime} 771.80$ & $0.79 \%$ \\
\hline 18 & Smith Fleming \& Co & $80^{\prime} 741.91$ & $0.79 \%$ \\
\hline 19 & Consolidated Bank & $80^{\prime} 253.50$ & $0.78 \%$ \\
\hline 20 & R \& J Henderson & $77^{\prime} 485.63$ & $0.76 \%$ \\
\hline 21 & Oriental Bank Corporation & $77^{\prime} 025.64$ & $0.75 \%$ \\
\hline 22 & Finlay Campbell \& Co & $75^{\prime} 030.05$ & $0.73 \%$ \\
\hline 23 & Merchant Banking Co of London & $72^{\prime} 484.53$ & $0.71 \%$ \\
\hline 24 & Dickinson W \& Co & $62^{\prime} 141.31$ & $0.61 \%$ \\
\hline 25 & Glyn Mills Currie \& Co & $61^{\prime} 882.74$ & $0.60 \%$ \\
\hline & TOTAL & $41^{\prime} 157.91$ & $39.5 \%$ \\
\hline
\end{tabular}

Source: Authors, from database. 
Figures 1a and 1b: Total amounts discounted, advanced, and rejected by the Bank of England.
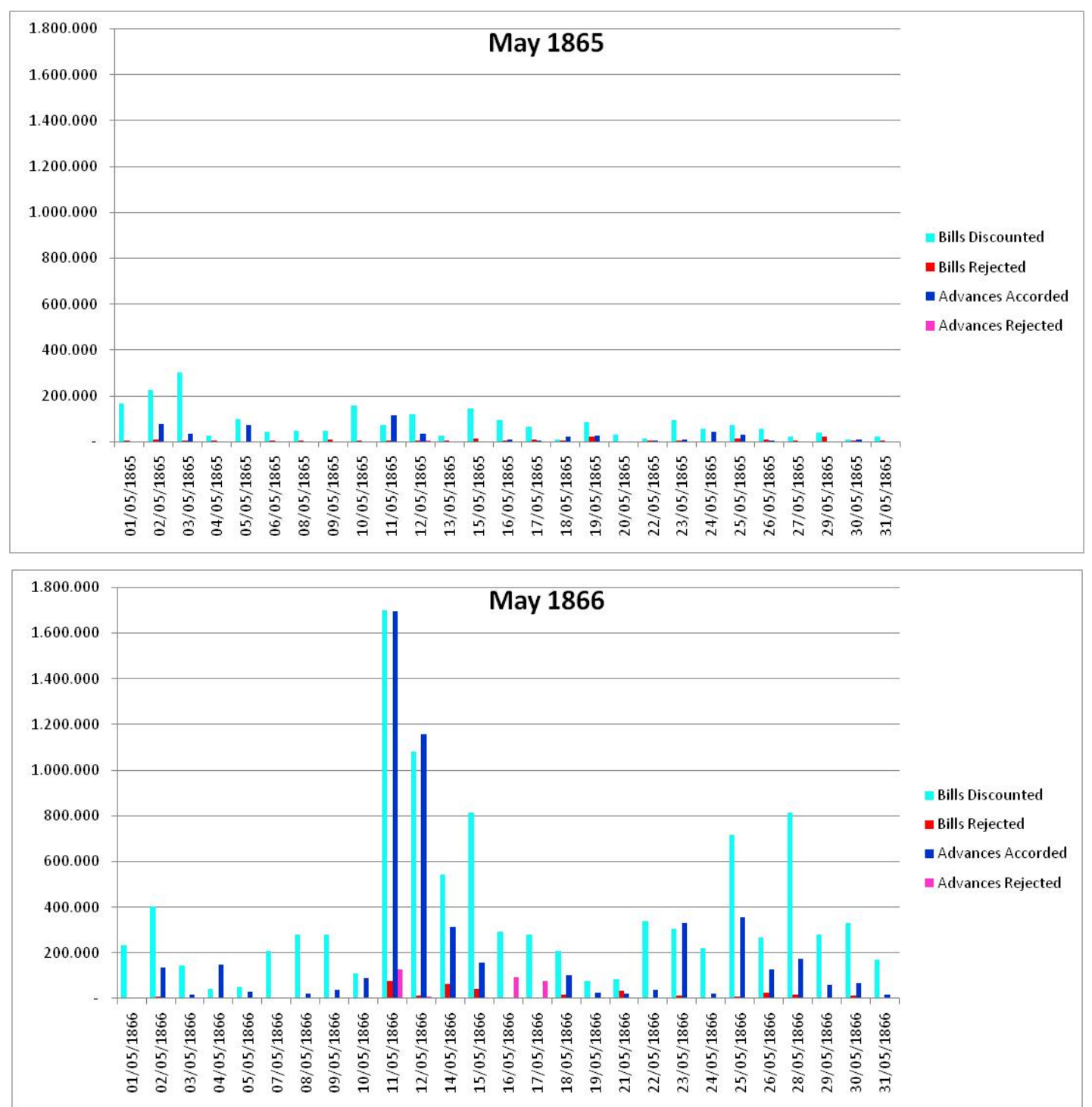

Source: Bank of England Archive, Daily Discounts, C 28/25-26. 
Figures 2a and 2b: Total amounts discounted by the Bank of England, per type of customer.
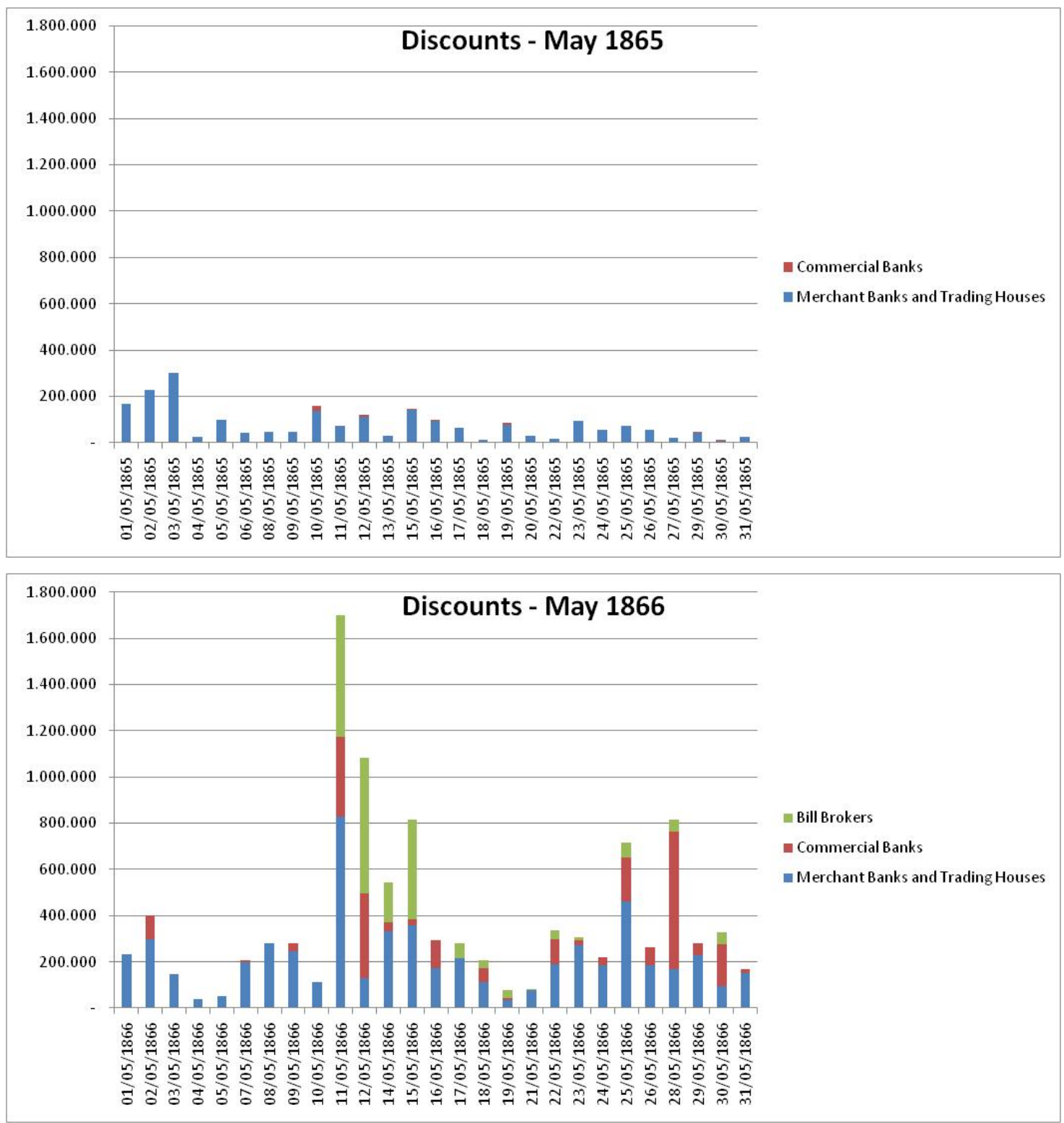

Source: Authors, from database. 
Figures 3a and 3b: Total amounts advanced by the Bank of England, per type of customer.
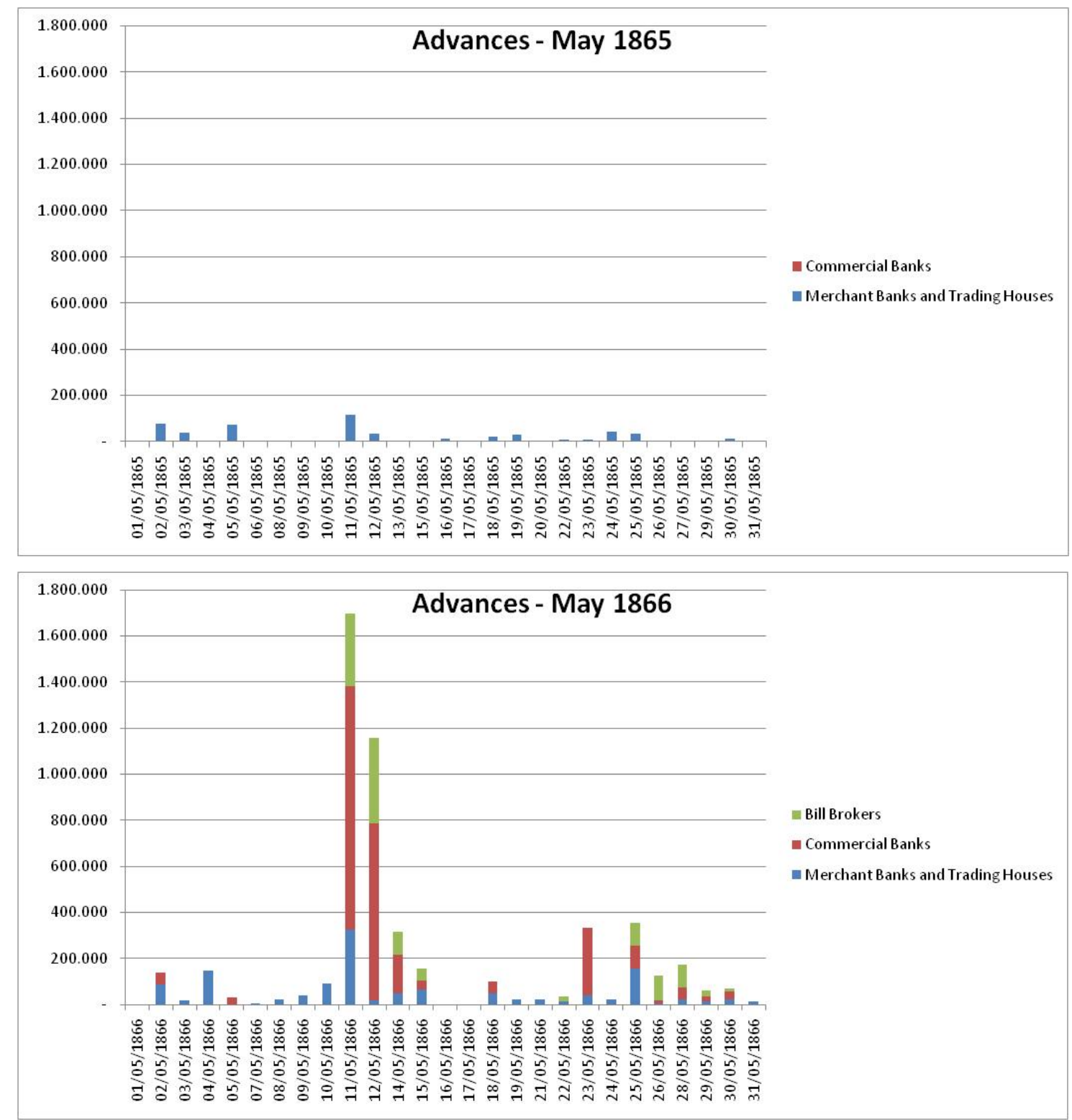

Source: Authors, from database. 
Figures $4 \mathrm{a}$ and $\mathrm{b}$ : Pareto curves for borrowers at the Bank: cumulative proportion of loans by $\mathrm{x} \%$ smallest borrower.
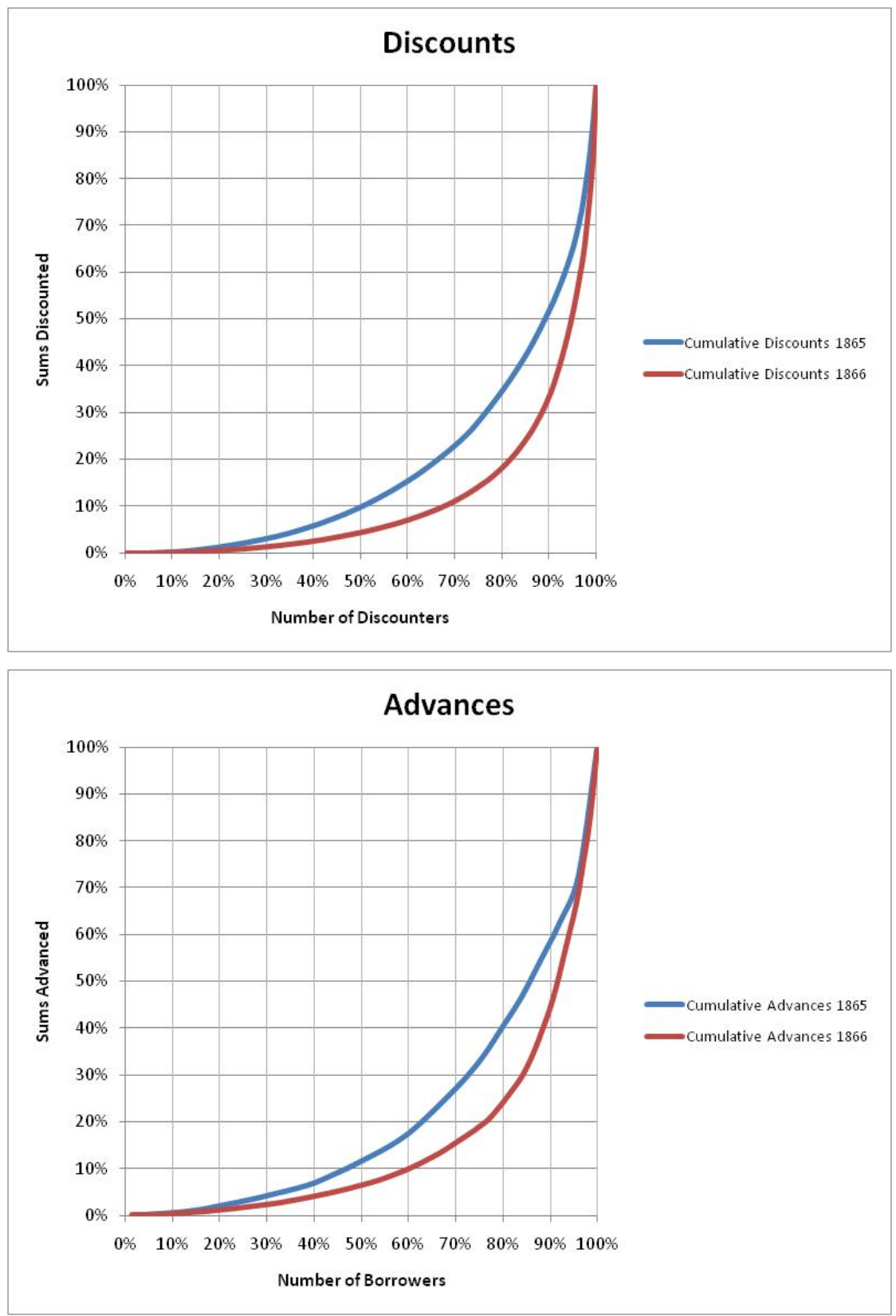

Source: Authors, from database. 
Figures 5a and $\mathrm{b}$ : Top discounters at the Bank of England, per type of customer.
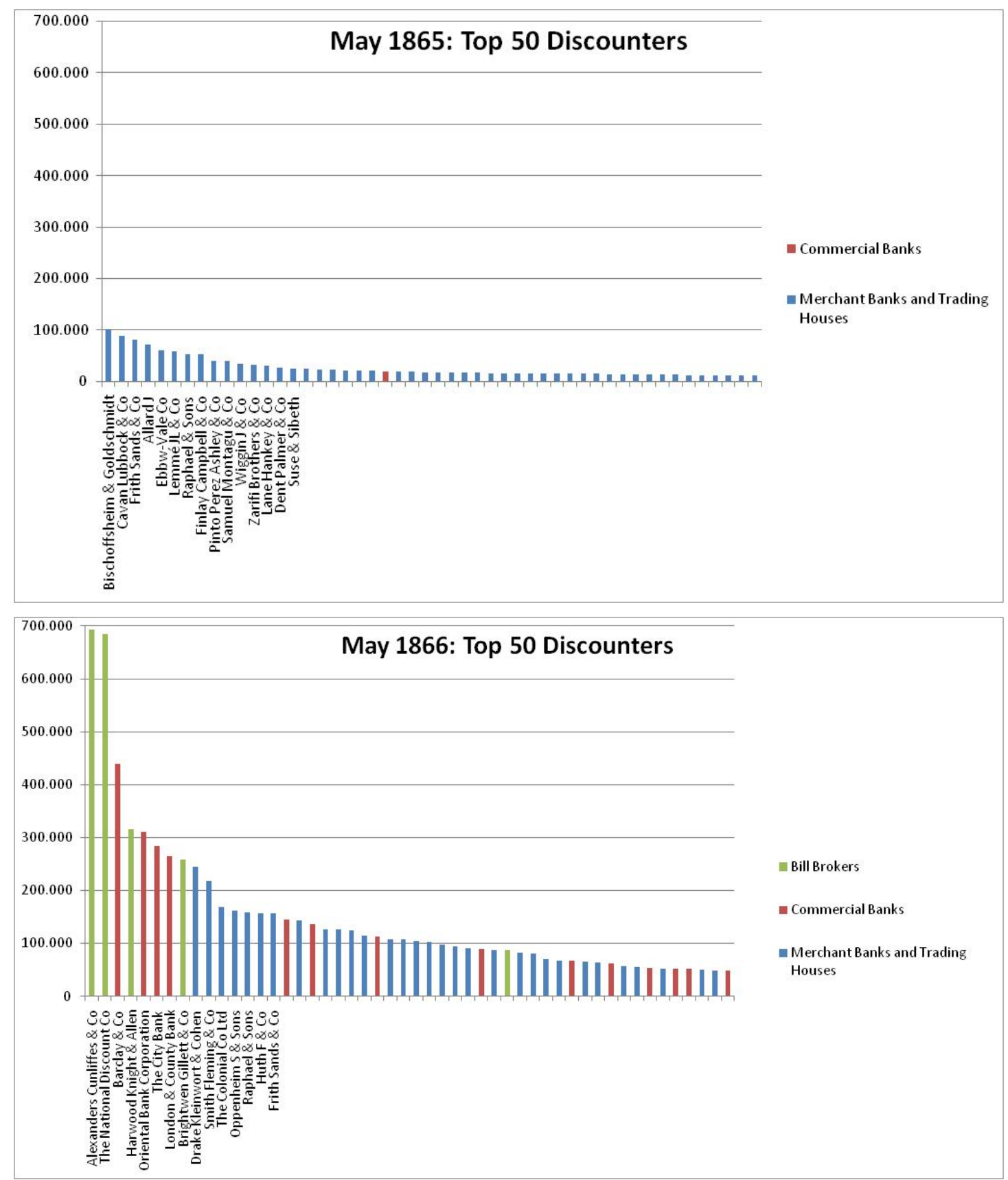

Source: Authors, from database. 
Figures 6a and b: Top advances at the Bank of England, per type of customer.
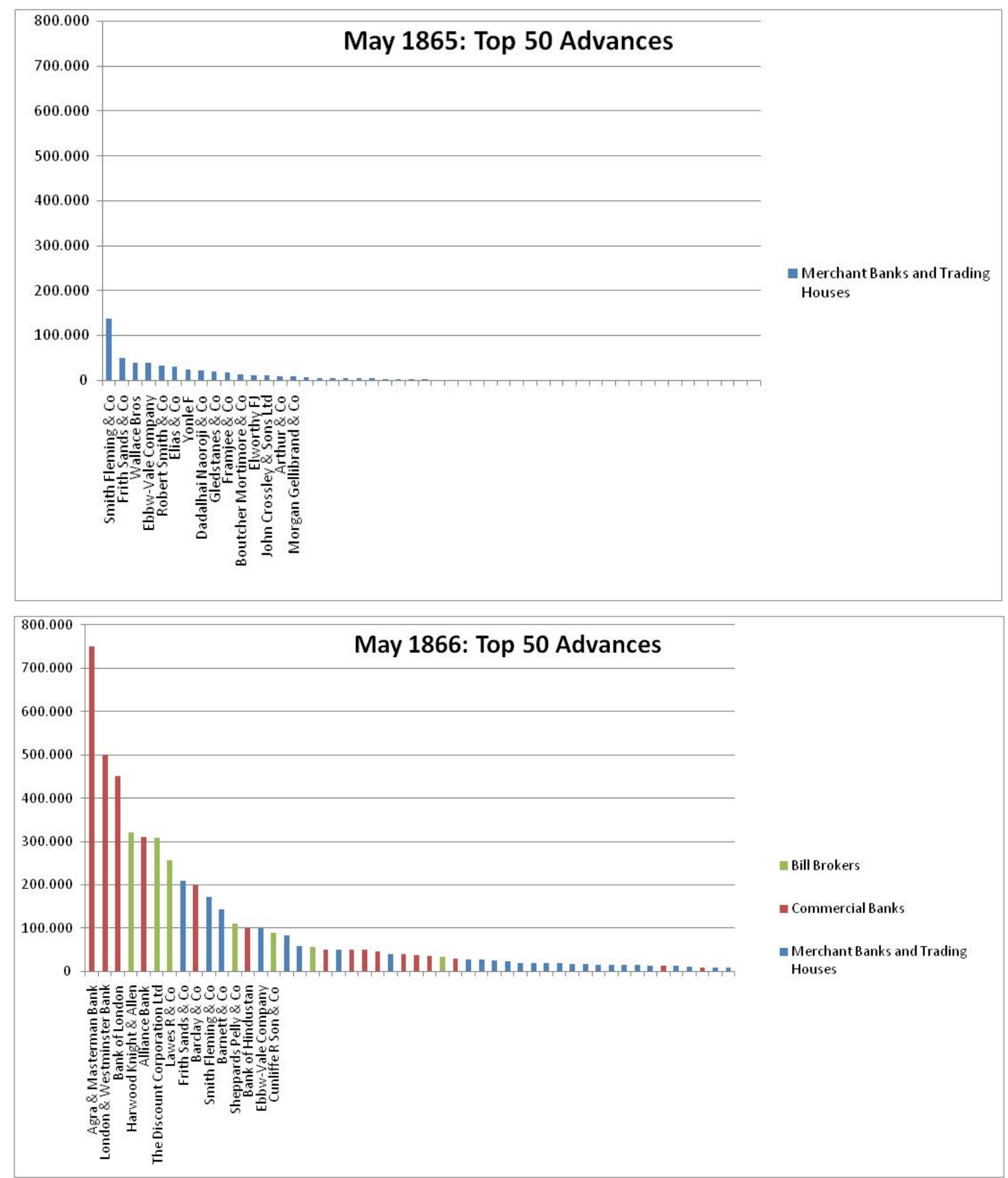

Source: Authors, from database. 
Figure 7. Share of Foreign Bills in Bank of England's Discounts during the 1850s.

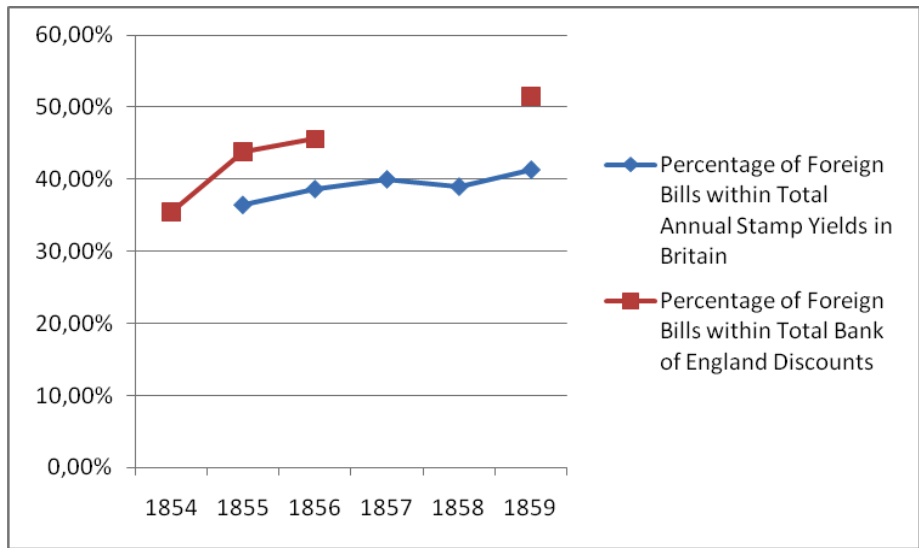

Source: Bank of England Archive C28/14-19, and Hughes (1960, p. 299). 
Figure 8: Breakdown inland vs. foreign bills (estimates are taken from the "top discounters" sample, and then normalized for the true total of discounts provided by the daily discounts ledgers).

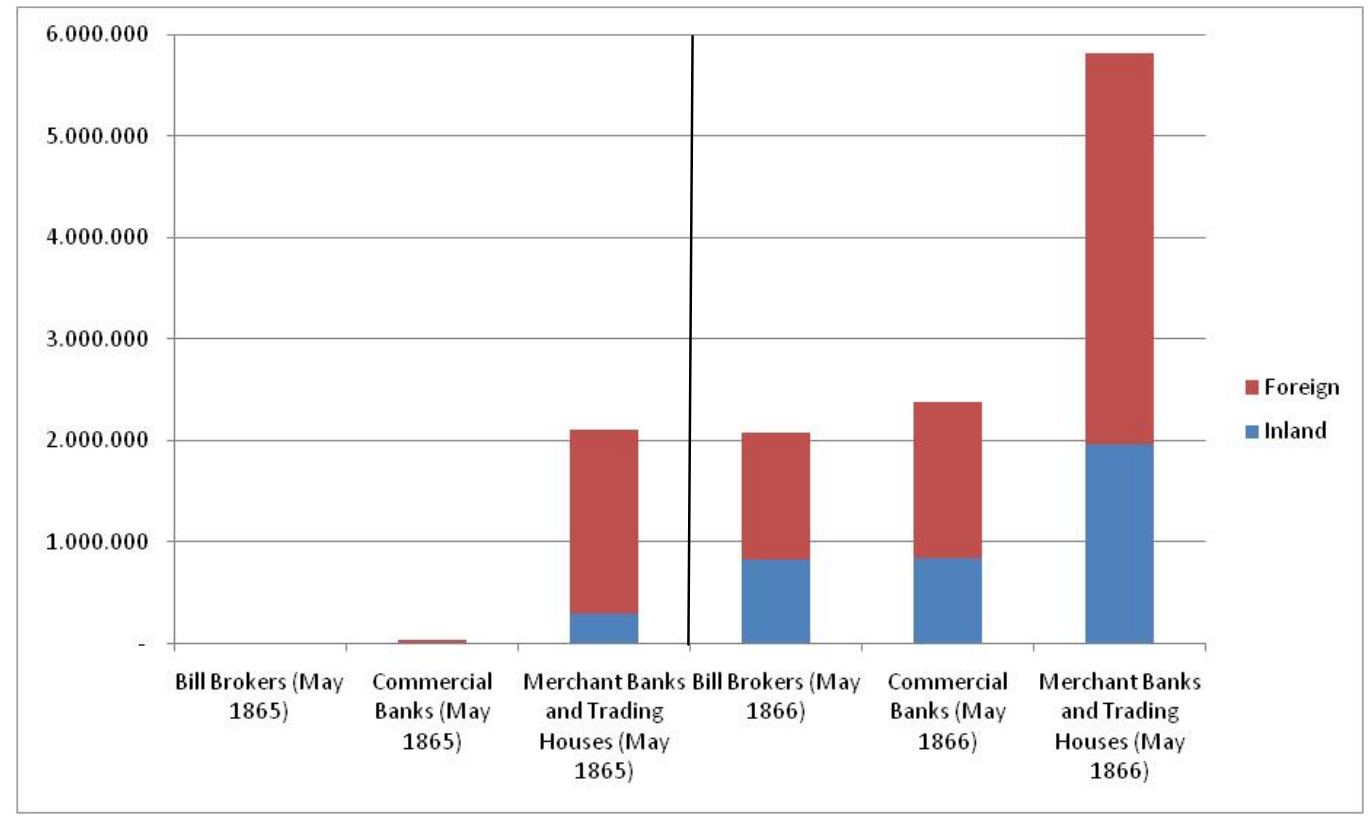

Source: Authors, from database. 
Figure 9. Market shares of top discounters and top acceptors.

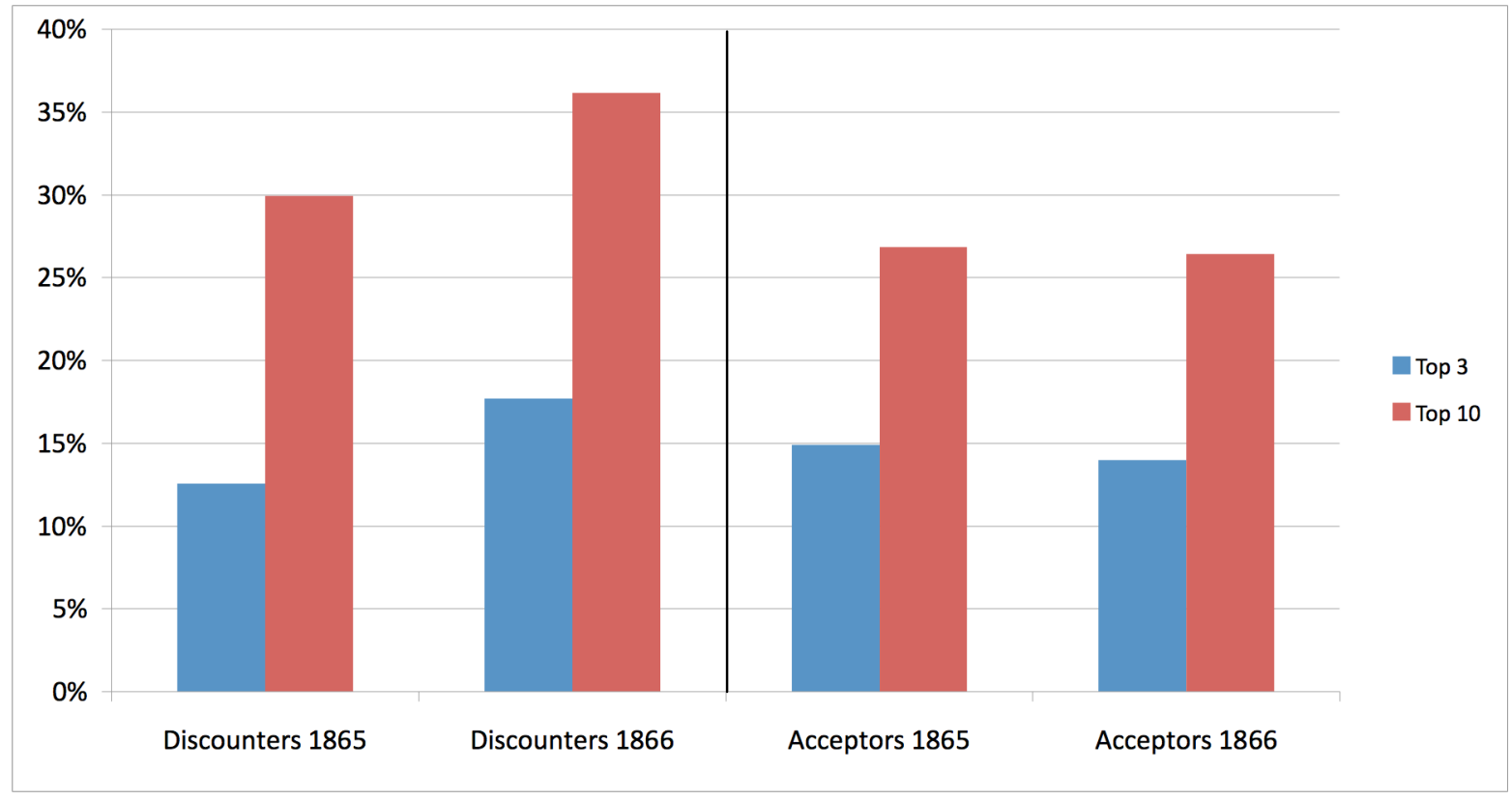

Source: Authors, from database. 
Figures $10 \mathrm{a}$ and $\mathrm{b}$. Geography of drawers for a selection of leading acceptors.
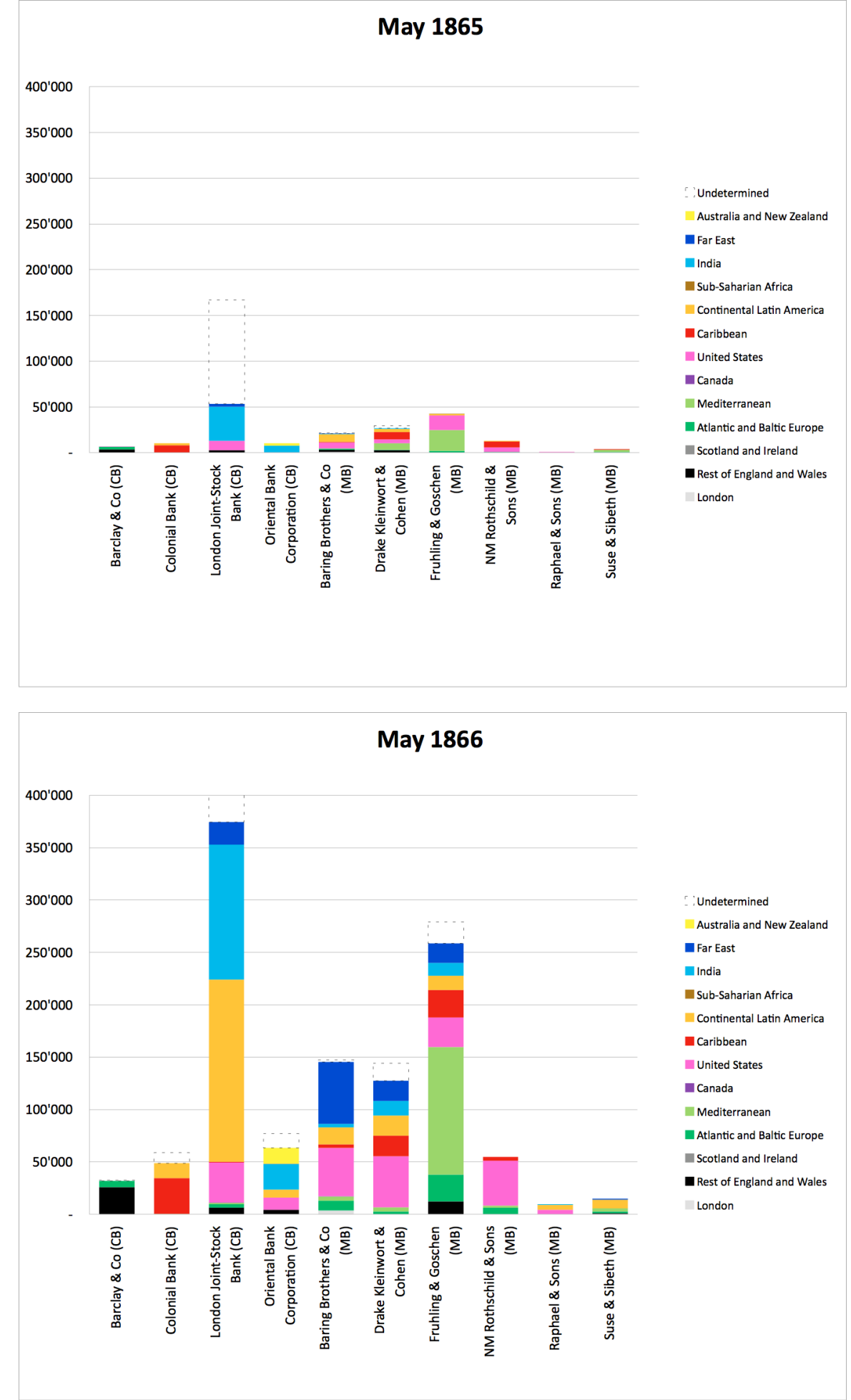

Source: Authors, from database. 
Figure 11. Breakdown of British trade (1865) and of the geography of drawers of the bills included in the "top discounters" sample (May 1865 and May 1866).

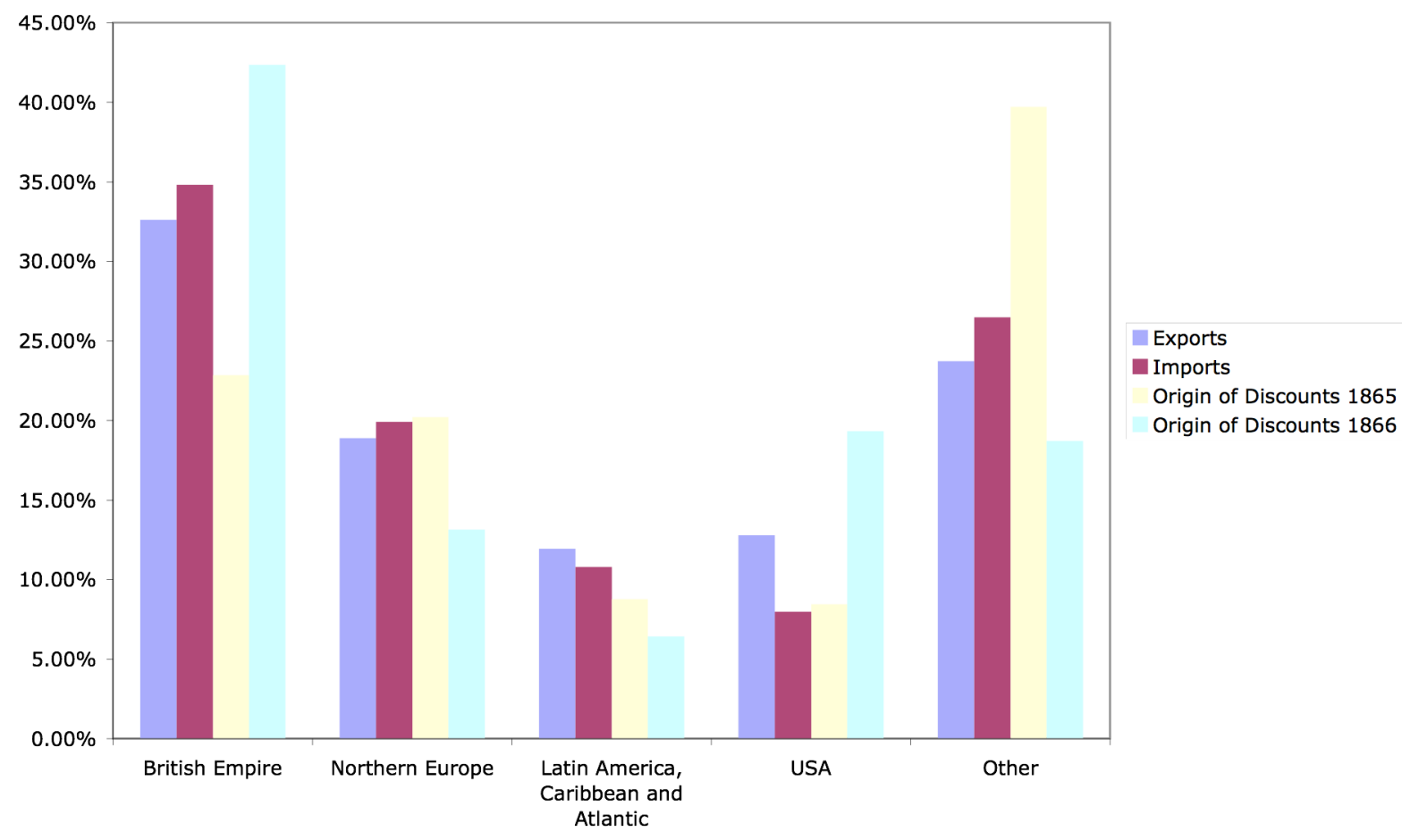

Source: Authors, from database and Statistical Abstract. 
Appendix. Figure A.1, An excerpt from the "Daily Discounts" ledgers, May 3rd, 1866 (Background picture for Table 1).

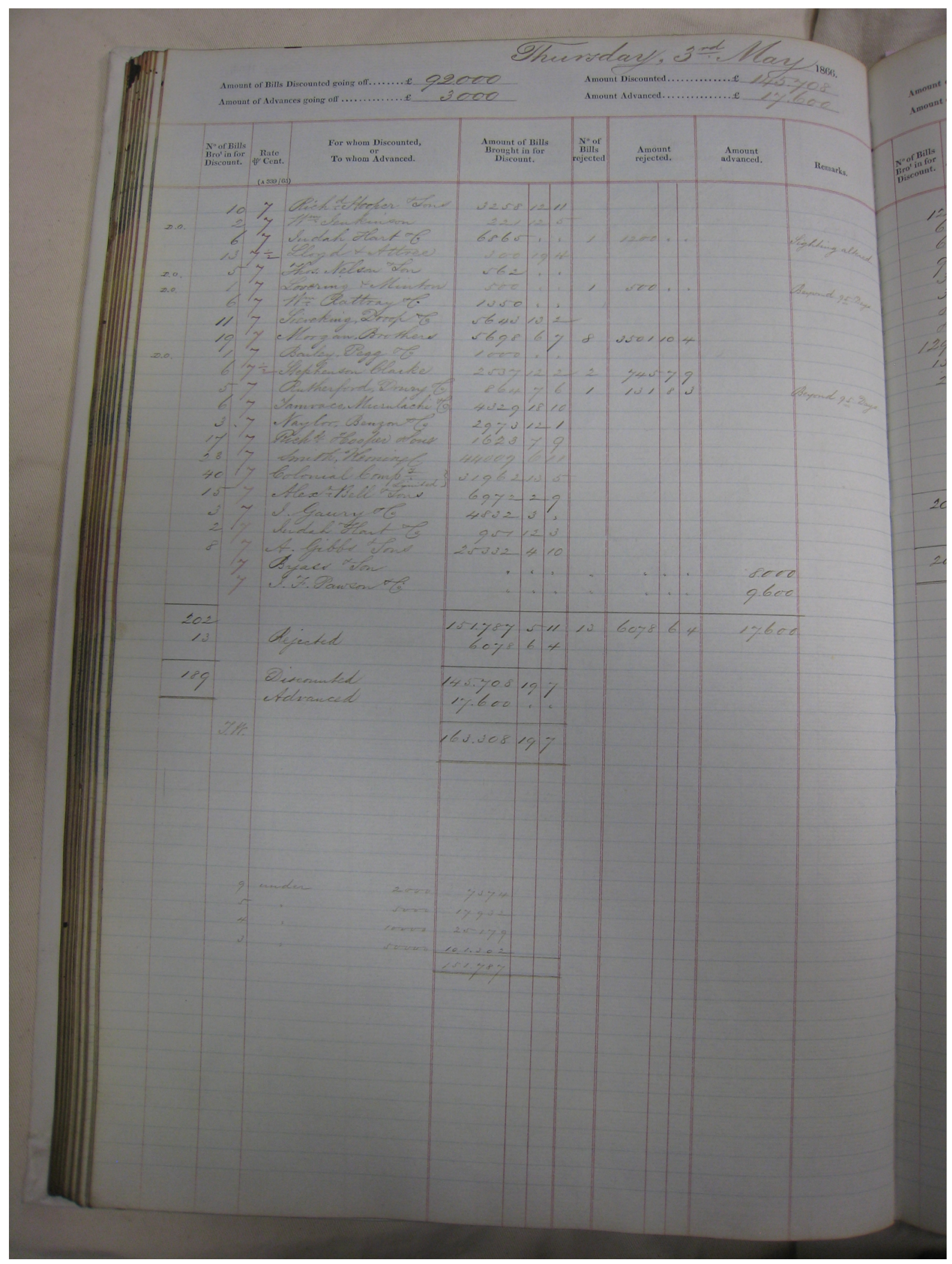

Source: Bank of England Archive, Daily Discounts 1866, C28/26. 